\title{
The bees of the genus Centris Fabricius, 1804 described by Theodore Dru Alison Cockerell (Hymenoptera: Apidae)
}

\author{
Felipe VIVALLO \\ HYMN Laboratório de Hymenoptera, Departamento de Entomologia, Museu Nacional, \\ Universidade Federal do Rio de Janeiro, Quinta da Boa Vista, \\ São Cristóvão 20940-040 Rio de Janeiro, RJ, Brazil. \\ Email: fvivallo@yahoo.com
}

urn:lsid:zoobank.org:author:AC109712-1474-4B5D-897B-1EE51459E792

\begin{abstract}
In this paper the primary types of Centris bees described by the British entomologist Theodore Dru Alison Cockerell deposited in the Natural History Museum (London) and the Oxford University Museum of Natural History (Oxford) in the United Kingdom, as well as in the United States National Museum (Washington), American Museum of Natural History (New York), the Academy of Natural Sciences of Drexel University (Philadelphia), and in the California Academy of Sciences (San Francisco) in the United States were studied. To stabilize the application of the name C. lepeletieri (= C. haemorrhoidalis (Fabricius)), a lectotype is designated. The study of the primary types allow proposing the revalidation of $C$. cisnerosi nom. rev. from the synonymy of $C$. agilis Smith, $C$. nitida geminata nom. rev. from C. facialis Mocsáry, C. rufulina nom. rev. from C. varia (Erichson), C. semilabrosa nom. rev. from C. terminata Smith and C. triangulifera nom. rev. from C. labrosa Friese. Centris bakeri syn. nov., C. bimaculata carrikeri syn. nov., C. fusciventris matoensis syn. nov., C. heterodonta syn. nov. and $C$. elegans grenadensis syn. nov. are proposed as a new junior synonyms of $C$. varia, C. claripennis Friese nom. rev., $C$. caurensis, $C$. dentata Smith and C. elegans Smith, respectively. Centris ruae is withdrawn from the synonymy of $C$. transversa Pérez and proposed as a new junior synonym of $C$. nitida Smith. In addition, a lectotype for $C$. buchholzi Herbst $(=C$. wilmattae) is designated. Information on the repository of the lectotype of $C$. lepeletieri and images of most primary types studied here are also provided.
\end{abstract}

Keywords. Anthophila, Centridini, Neotropical region, New World, solitary bees, taxonomy.

Vivallo F. 2020. The bees of the genus Centris Fabricius, 1804 described by Theodore Dru Alison Cockerell (Hymenoptera: Apidae). European Journal of Taxonomy 618: 1-47. https://doi.org/10.5852/ejt.2020.618

\section{Introduction}

Theodore Dru Alison Cockerell (1866-1948) was a British entomologist, systematic biologist and one of the most important melittologist of all time (Engel \& Davis 2012). His contributions to science began during the early years of his youth. Throughout his more than four decades of activity, Cockerell published more than 3900 articles (Zuparko 2007), becoming one of the most proliferous scientists of 
his time. Despite his large number of publications, Cockerell was harshly criticized by other colleagues because some of his articles were exaggeratedly short and incomplete (Gardner 1999; Zuparko 2007).

As a child, Cockerell was interested in every phase of natural history, and this broad interest and enthusiasm continued until his death (Michener 1948). He wrote extensively on land snails, moths, slugs, fungi, mollusks, fossil insects, fish scales, sunflower taxonomy, genetics and paleobotany (Michener 1948; Gardner 1999), but his most numerous contributions were on scale insects and bees.

In 1887, Cockerell moved from Norwood, his natal city in the United Kingdom, to Westcliff, a small town in south-central Colorado, United States, and there he began working as a biologist (Michener 1948; Rohwer 1948). Thirteen years later, he returned to England, where he started working at the British Museum (Michener 1948), nowadays the Natural History Museum, London (NHMUK). There, he met the renowned British explorer, naturalist and geographer Alfred Russel Wallace (1823-1913). Cockerell became Wallace's assistant, helping him to edit the second edition of his classic "Island Life" (Weber 2004). Cockerell and Wallace maintained a close personal and professional relationship until the day of Wallace's death in November 1913 (Gardner 1999).

In 1891, Cockerell married Annie Sarah Fenn (1857-1893) (Rohwer 1948); he left the British Museum and moved with his wife to Jamaica, where he worked as curator of the Public Museum of Kingston (Michener 1948). That was Cockerell's first introduction to the tropics. During his stay on the island, he developed an intense interest in scale insects, beginning his study on the family Coccidae Fallén, 1814 (Hemiptera Linnaeus, 1758), which continued for many years (Rohwer 1948). In just a couple of years, Cockerell recorded by himself more species for that country than had previously been reported from all the West Indies (Schwarz 1948).

Two years later, Cockerell and his wife left Jamaica and settled in New Mexico, United States. There he exchanged positions with the American entomologist and dipterologist Charles Henry Tyler Townsend (1863-1944) (Michener 1948; Rohwer 1948). Cockerell became Professor of Entomology and Zoology in 1893 at the New Mexico Agricultural College, Las Cruces (Gardner 1999), currently known as New Mexico College of Agriculture and Mechanic Arts, New Mexico State University. During his stay in that institution, Cockerell began his studies on Hymenoptera, mainly focusing on bees (Michener 1948). These insects were extremely numerous in New Mexico and the majority of them undescribed (Cockerell 1935a). Wild bees interested him perhaps more than any other form of life (Schwarz 1948). Shortly after their arrival in New Mexico, Cockerell's wife died (Rohwer 1948).

Some years later, Cockerell married the American botanist and entomologist Wilmatte Porter (1869-1957) with whom he moved to Boulder, Colorado (Rohwer 1948). Between 1906 and 1934, he was a professor of Zoology at the University of Colorado (Gardner 1999) and after his retirement, he maintained an office there, but spent part of each year elsewhere, usually in California.

Between 1946 and 1947, Cockerell visited the Escuela Agrícola Panamericana in Tegucigalpa, Honduras, for approximately six months; there he collected many bees (Michener 1948). The specimens studied were included in what would be his last article published on Honduran bees (Cockerell 1949), which was assembled by the American hymenopterist Karl Vorse Krombein (1912-2005) after Cockerell's death.

\section{Cockerell's bees}

Cockerell is, until today, considered one of the most prolific melittologists of all time. The descriptions of bees believed to be new was only part of his work. Extension of the geographic range of species already known was another substantial contribution. Through one channel of publication alone - Annals 
and Magazine of Natural History - he issued about 200 successive papers devoted to descriptions and records of bees (Schwarz 1948).

Although his work is largely purely descriptive, he also made careful observations and insights into innumerable aspects of evolutionary biology (Engel \& Davis 2012). Cockerell never found fault when other researchers, with more material available and after more thorough study, placed his names in synonymy; indeed, he treated many of his own names in the same way himself (Michener 1948).

Altogether, Cockerell described approximately 5500 species, subspecies and varieties of bees from different parts of the world, as well as almost 150 genera and subgenera (Gardner 1999). His broad vision and knowledge about the taxonomy at different levels allowed him to make contributions in all bee families, and unlike many researchers who describe great numbers of new organisms, he never attempted to maintain a monopoly in any of the groups in which he was interested (Michener 1948).

According to current estimates, the number of bees, including the species currently considered valid and those still unknown to science, would approximately be 20000 (Michener 2007). On the basis of this estimate, which is probably not excessive, one can visualize the magnitude of the individual contribution of Cockerell in making known the diversity of these insects (Schwarz 1948).

Despite the fact that a large part of his articles dealt with the fauna of the United States, his contributions were not limited to specific zones, countries, or biogeographical regions. Of the total number of bees described by Cockerell, approximately 450 occur in the Neotropics (see Moure et al. 2007). In this biogeographic region, the species of the genus Centris Fabricius, 1804 represent one of the most important and diverse groups of solitary bees (Vivallo 2013), and as in many other groups, Cockerell also made important contributions to the knowledge of this lineage of bees.

In this genus, Cockerell proposed 37 species and 18 subspecies published in 24 articles. Of the total species he described, one was erroneously placed in the genus Hemisia Klug, 1807, a junior synonym of Centris, and two in Epicharis Klug, 1807 (see Cockerell 1949). The species proposed by him are: C. caesalpiniae Cockerell, 1897, C. caesalpiniae rhodopus Cockerell, 1897, C. hoffmanseggiae Cockerell, 1897 (Fig. 22), C. hoffmanseggiae davidsoni Cockerell, 1904, C. morsei Cockerell, 1897 (Fig. 23) and C. rhodopus pulchrior Cockerell, 1900 (Fig. 24) from the United States; C. atripes ferrisi Cockerell, 1924, C. cockerelli resoluta Cockerell, 1923, C. pallida callognatha Cockerell, 1923, C. rhodoleuca Cockerell, 1923, C. tiburonensis Cockerell, 1923, C. trichosoma Cockerell, 1923 and C. vanduzeei Cockerell, 1923 from Mexico; C. adani Cockerell, 1949 (Fig. 2), C. cisnerosi (Cockerell, 1949) (Fig. 21), C. durantae Cockerell, 1949 (Fig. 15), C. inermis pallidifrons Cockerell, 1949 (Fig. 6), C. lanipes subtarsata Cockerell, 1949 (Fig. 10), C. petreae Cockerell, 1949 (Fig. 16), C. petreae rufopicta Cockerell, 1949, C. robusta Cockerell, 1949 (Fig. 7), C. ruae Cockerell, 1949 (Fig. 13), C. rufomaculata Cockerell, 1949 (Fig. 14), C. triangulifera Cockerell, 1949 (Fig. 17) and C. zamoranensis (Cockerell, 1949) (Fig. 20) from Honduras; C. inermis gualanensis Cockerell, 1912 (Fig. 5) and C. schwarzi Cockerell, 1919 (Fig. 28) from Guatemala; C. calloxantha Cockerell, 1919 (Fig. 30), C. chlorura Cockerell, 1919 (Fig. 25), C. escomeli Cockerell, 1926 (Fig. 29), C. euphenax Cockerell, 1913, C. lilacina Cockerell, 1919 (Fig. 1), C. pachysoma Cockerell, 1919 (Fig. 27) and C. wilmattae Cockerell, 1926 from Peru; C. bakeri Cockerell, 1912, C. ceratocephala Cockerell, 1912, C. heterodonta Cockerell, 1912, C. libertatis Cockerell, 1912 and C. merrillae Cockerell, 1919 (Fig. 11) from Brazil; C. nitens callospila Cockerell, 1937, C. lanipes ogilviei Cockerell, 1936 and C. rufulina Cockerell, 1937 from Guyana; C. disclusa Cockerell, 1922 (Fig. 3), C. nitida geminata Cockerell, 1914 (Fig. 9) and C. semilabrosa (Cockerell, 1910) from Ecuador; C. bimaculata carrikeri Cockerell, 1919 (Fig. 26), C. fusciventris caurensis Cockerell, 1919 (Fig. 18) and C. fusciventris matoensis Cockerell, 1919 (Fig. 19) from Venezuela; C. maroniana Cockerell, 1917 from French Guiana, and the Caribbean 
species C. barbadensis Cockerell, 1939 and C. rhodadelpha Cockerell, 1939 (Fig. 12) from Barbados; C. elegans grenadensis Cockerell, 1919 (Fig. 4) from Grenada; C. versicolor vincentana Cockerell, 1938 (Fig. 8) from Saint Vincent and the Grenadines; C. lepeletieri Cockerell, 1912 from the Dominican Republic; and C. rufosuffusa Cockerell, 1935 from Trinidad and Tobago.

Although Cockerell described a considerable number of new taxa - 55 species and subspecies - in Centris, more than half of them are currently considered synonyms (see Moure et al. 2007). This is somewhat recurrent in other groups of bees described by him, probably due to the fact that many of his species were described based on coloration, without neither considering the variation of this character, nor using more robust morphological features that could support them as valid species.

The purpose of this article is to study taxonomically all species and subspecies of Centris bees described by Cockerell. For this purpose, their taxonomic status is evaluated, and information is provided on the condition and depository of the primary types used by him to describe each taxon.

\section{Material and methods}

All labels are here considered whitish and rectangular, and the data contained on them is black, handwritten or printed, unless otherwise indicated. The specific features of the labels, like coloration or type of writing, are given in squared brackets ([ ]). All yellow labels contain a barcode, which is part of the database of the United States National Museum collection (NMNH). Some information on the handwritten labels is difficult to decipher, in these cases the symbol '[?]' was used. The backward slash $(\backslash)$ indicates different labels on the pin of the same specimen and two backward slashes ( $\backslash$ ) indicate information on the back of the label.

\section{Institutional abbreviations}

AMNH $=$ American Museum of Natural History, New York, United States
ANSP
CAS Academy of Natural Sciences of Drexel University, Philadelphia, United States
HNHM $=$ California Academy of Sciences, San Francisco, United States
MCZ $=$ Magyar Természettudományi Múzeum, Budapest, Hungary
MNHN $=$ Muséum national d'histoire naturelle, Paris, France
MPEG $=$ Museu Paraense Emílio Goeldi, Belém, Brazil
NHMD $=$ Natural History Museum of Denmark, Copenhagen, Denmark
NHMUK $=$ Natural History Museum, London, United Kingdom
NMNH $=$ United States National Museum, Washington, United States
OUMNH $=$ Oxford University Museum of Natural History, Oxford, United Kingdom
ZMB $=$ Museum für Naturkunde, Berlin, Germany

The copyright of the photographs belongs to the NMNH. The information related is provided with the permission of the National Museum of Natural History, Smithsonian Institution, $10^{\text {th }}$ and Constitution Ave. N.W., Washington, DC 20560-0193 (https://www.nmnh.si.edu/).

\section{Results}

\section{Recognition of the type specimens}

According to Cockerell (1949), he divided his collection of Neotropical bees in two parts; one was sent to the NMNH and the other to the AMNH. These two institutions house more than $2 / 3$ of the primary types of Centris bees described by him. The rest of the type specimens are deposited, in decreasing order, in the collections of CAS, NHMUK, ANSP, OUMNH and ZMB. All primary types currently 
housed at CAS, except for C. hoffmanseggiae davidsoni, were collected by the American entomologist and curator of the Department of Entomology of the California Academy of Sciences Edward Payson Van Duzee (1861-1940) (MacFarland 1940). Probably, Cockerell studied these specimens at CAS during a visit to California. It is not clear whether the specimens currently housed at NHMUK already belonged to that collection or whether they were part of Cockerell's own collection and were sent there subsequently. Part of the type series of C. caesalpiniae and C. caesalpiniae rhodopus is currently housed at ANSP. Those specimens bear a printed label: "1980 Loan to USNM from Acad. of Nat. Sciences at Philadelphia". No additional information about this was found.

All Cockerell's primary types can be easily recognized by his handwriting style (see Horn \& Kahle 1935: pl. 3, fig. 18). He labeled almost all the specimens he used in the original descriptions with the name of the species and the words "type", "cotype" or "co-type". Along with these labels, the data on collector, provenance and depository agreed with those mentioned by him in the original descriptions. Considering this, I am confident that the specimens examined are true Cockerell's primary types and fully valid for the proposal of revalidations and new synonymies, as well as for the designation of lectotypes when necessary.

\section{Systematics}

Genus Centris Fabricius, 1804

Subgenus Centris (Aphemisia) Ayala, 2002

Centris lilacina Cockerell, 1919

Fig. 1

Centris lilacina Cockerell, 1919: 191-192.

\section{Type data}

This species was described based on a single female specimen collected by the English traveler, naturalist, ornithologist and entomologist William Frederick Henry Rosenberg (1868-1957) who made collecting trips to northern South America (Günter 1912). The holotype (Fig. 1) is housed at the NMNH under the number 21656 and has the following data label: Palcazu Peru [printed] Collection Rosenberg Centris lilacina Ckll type. [handwritten] \red label] Type No. [printed] 21656 [handwritten] U.S.N.M.
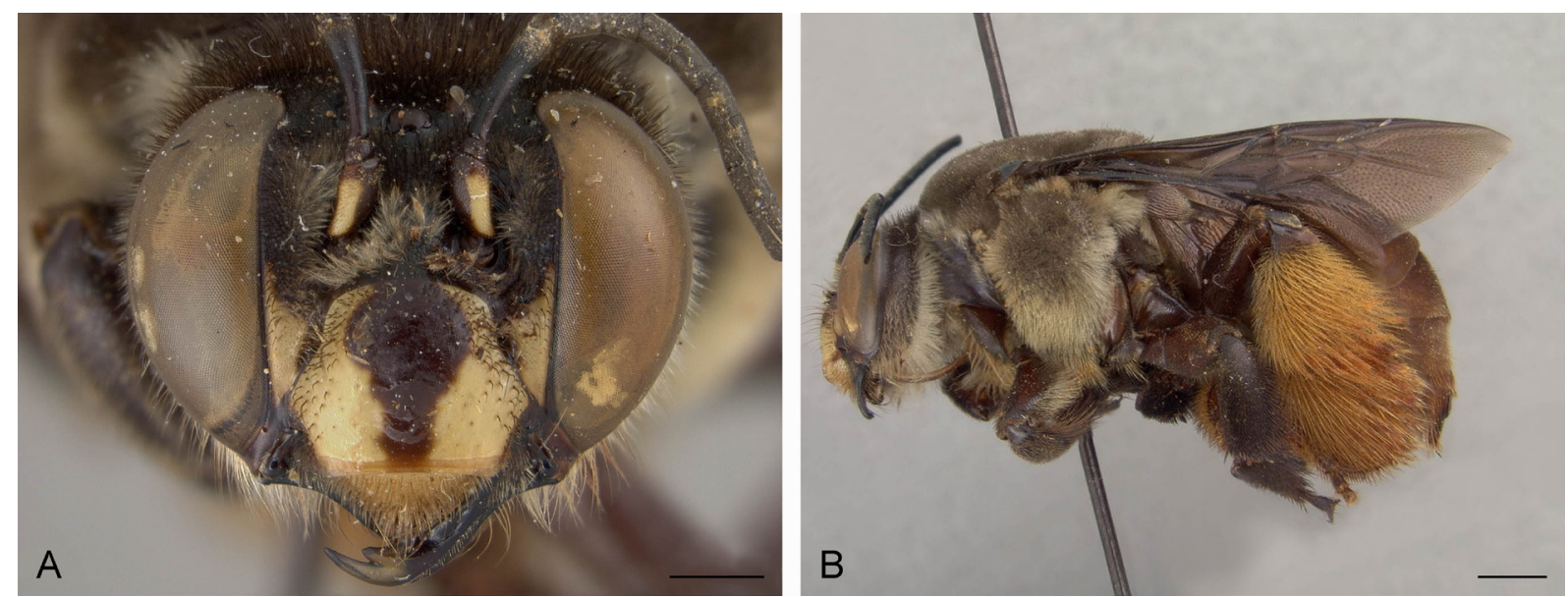

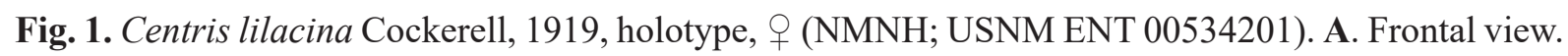
B. Habitus, lateral view. Scale bars: $A=1 \mathrm{~mm} ; \mathrm{B}=2 \mathrm{~mm}$. 
[printed] [yellow label] USNM ENT 00534201 [barcode] $\backslash$ DO NOT REMOVE SI DB Reference Not a property tag T. Schultz NMNH [printed].

\section{Type locality}

Peru: Pasco department: Palcazú.

\section{Comments}

This species was correctly interpreted by Moure (2002) and Moure et al. (2007). Erroneously, Moure (2002) considered the specimen housed at NMNH a syntype.

\section{Subgenus Centris (Centris) Fabricius, 1804}

Centris adani Cockerell, 1949

Fig. 2

Centris (Cyanocentris) adani Cockerell, 1949: 472-473.

\section{Type data}

This species was described based on a single female specimen collected by Adan Rivera on February 9, 1948, at Zamorano, Honduras. Rivera and G. Cisneros were probably collectors who helped Cockerell during his stay in Honduras (Jesus Orozco, pers. com.). The holotype (Fig. 2) is currently housed at NMNH under the number 58878 and has the following data label: 192 [handwritten] Zamorano Honduras Feb.9. [handwritten] Arivera [?] Centris adani Ckll Type. [handwritten] [red label] Type No 588878 [handwritten] USNM [printed] [yellow label] USNM ENT 00534186 [barcode] [printed] $\backslash$ DO NOT REMOVE SI DB Reference Not a property tag T. Schultz NMNH [printed].

\section{Type locality}

Honduras: Francisco Morazán department: Zamorano.
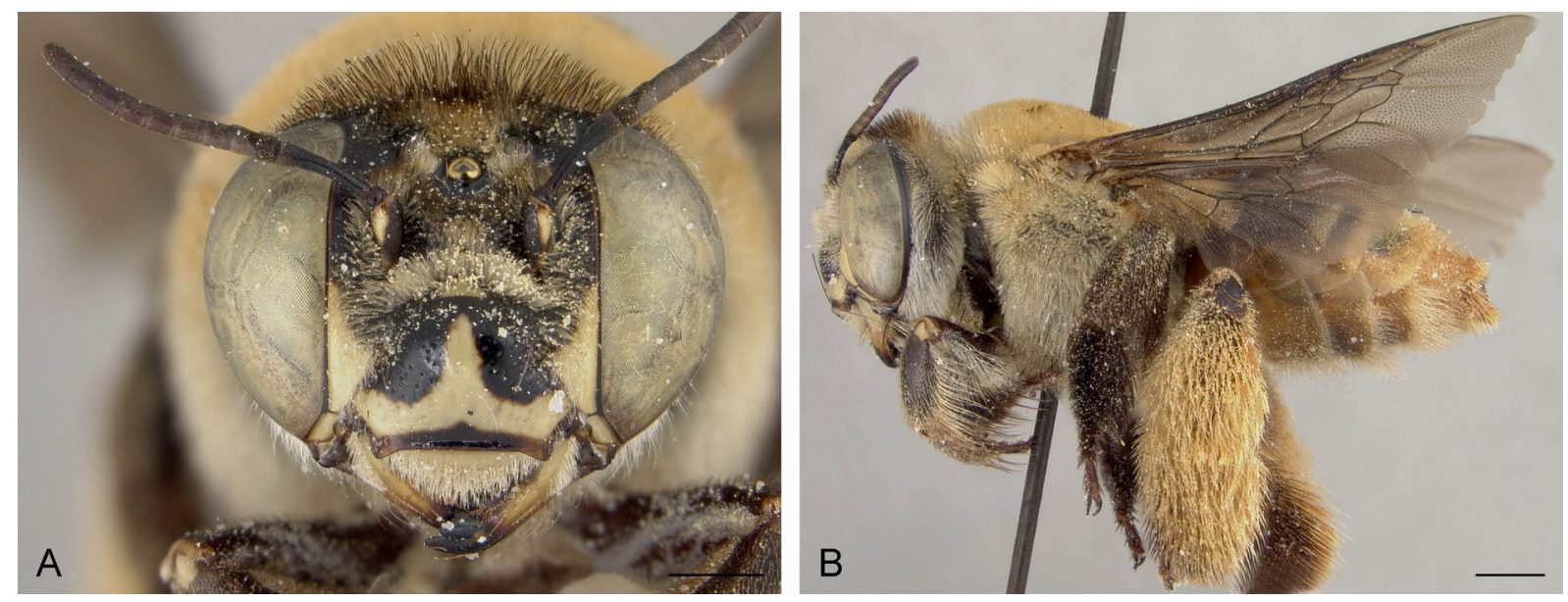

Fig. 2. Centris adani Cockerell, 1949, holotype, $q$ (NMNH; USNM ENT 00534186). A. Frontal view. B. Habitus, lateral view. Scale bars: $A=1 \mathrm{~mm} ; B=2 \mathrm{~mm}$. 


\section{Comments}

Of the 12 species described by Cockerell in 1949, C. adani and C. cisnerosi nom. rev. are the only ones considered valid. The former species was correctly interpreted by Snelling $(1974,1984)$ and Moure et al. (2007).

Centris bakeri Cockerell, 1912

Centris (Hemisia) bakeri Cockerell, 1912a: 42-43.

New junior synonym of $C$. (Centris) varia (Erichson, 1848).

\section{Type data}

Cockerell (1912a) described this species from a single male specimen currently housed at AMNH. The holotype, as well as the primary types of $C$. heterodonta and $C$. libertatis (see below), were collected during the Stanford Expedition to Brazil between the mouth of the Amazon River and Rio Grande do Norte. The journey was coordinated by the American geologist and botanist John Casper Branner (18501922 ) and had as members, among others, Fred Baker (1854-1938), a malacologist of the San Diego Society of Natural History, and the student of zoology William Mann (1886-1960). Both Baker and Mann assisted in the work of the field trip (Oliveira 2014). According to Oliveira (2014), the researchers collected species on the coast and backlands of Ceará and Rio Grande do Norte States, as well as along the Madeira River, having spent a few months at the facilities of the Madeira-Mamoré Railway. The holotype has the following data label: Rio Madeira Brazil Mann \& Baker [printed] $\backslash$ Madeira-Mamore R.R. Co. Camp 43 [printed] \Centris bakeri Ckll. Type. [handwritten] $\backslash$ AMNH_IZC 00323432 [data matrix code] [printed].

\section{Type locality}

Brazil: Rondônia State: Rio Madeira.

\section{Comments}

The study of the type of Centris bakeri revealed that it corresponds to a male of $C$. varia with two yellow spots on the lateral surfaces of the second tergum. The coloration of the metasoma in both sexes of this species is very variable. Terga and sterna of specimens can be blackish, reddish brown or orange, with or without dark brown or yellowish spots or bands. Centris varia is one of the most widely distributed species of the subgenus $C$. (Centris). According to Moure et al. (2007), it occurs from Mexico to Argentina.

\section{Centris callospila Cockerell, 1937}

Centris (Hemisia) nitens callospila Cockerell, 1937a: 1.

\section{Type data}

This species was described based on a single male specimen collected by John W. Ogilvie at Waranama, northeastern Guyana, on November 14, 1936. Ogilvie was a Scottish immigrant who went to South America to establish his fortune in gold prospection and exploitation of rubber tapping (Pourshariati 2017). Ogilvie, along with other people, made an expedition through the Amazon that begun in Manaus, Brazil, and ended in Georgetown, Guyana. The purpose of that expedition was mainly ethnological (Pourshariati 2017); however, biological collections were also made. At least some of the bees obtained during that trip were studied by Cockerell (1936, 1937a, 1937b). Ogilvie also visited some Caribbean islands where he collected biological samples that were subsequently sent to other scientists 
for study (see Cockerell 1938, 1939). During the collection of this new species, other Centris bees were also caught (Cockerell 1937b). Ogilvie also captured specimens of $C$. denudans Lepeletier, 1841, C. flavifrons clitelligera (Erichson, 1848) (=C. flavifrons (Fabricius, 1775)) and C. nitens Lepeletier, 1841. The holotype of $C$. nitens callospila is currently housed at AMNH and has the following data label: Nov.14.J.O [handwritten] Waranama, B.G., Nov. 1936 Ogilvie, Coll. [printed] Centris callospila Ck1l. Type. [handwritten] $\backslash$ acC. 34970 [handwritten] $\backslash$ AMNH_IZC 00323434 [data matrix code] [printed].

\section{Type locality}

Guyana: Waranama.

\section{Comments}

Although Cockerell labeled the type specimen as a new species, it was published as a variety of C. nitens. This species is only known from male specimens and could actually correspond to a metander male of C. nitens.

\section{Centris disclusa Cockerell, 1922}

Fig. 3

Centris disclusa Cockerell, 1922: 5-6.

Junior synonym of $C$. (Centris) maculifrons Smith, 1854 (Moure et al. 2007).

\section{Type data}

This species was described based on two male specimens collected by Francisco Campos Ribadeneira in Posorja ("Posoya"), Ecuador. Campos (1878-1943) was an intellectual from Guayaquil and the first Ecuadorian entomologist (Barragán et al. 2009). He collected numerous insects and created the first entomological collection in that country (Moret 2005).

One of those males was found at NMNH under the number 24881 and bears an original Cockerell's label of type. The specimen (Fig. 3) has the following data label: Posorja Ecua FCamposR [printed] $\backslash$ Centris disclusa Ckll Type. [handwritten] [red label] Type No. [printed] 24881 [handwritten] [U.S.N.M.] [yellow label] USNM ENT 00534192 [barcode] [printed] \ DO NOT REMOVE SI DB Reference $\underline{\text { Not }}$
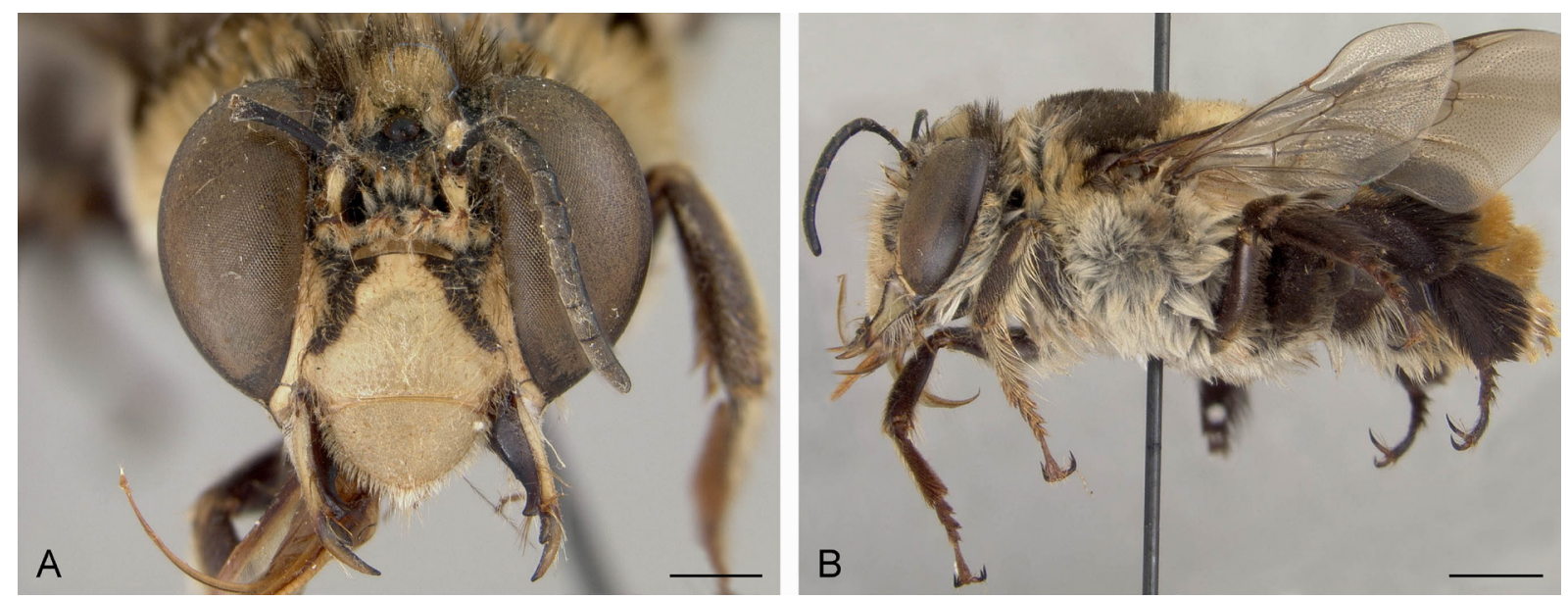

Fig. 3. Centris disclusa Cockerell, 1922, holotype, ô (NMNH; USNM ENT 00534192). A. Frontal view. B. Habitus, lateral view. Scale bars: $A=1 \mathrm{~mm} ; B=2 \mathrm{~mm}$. 
a property tag T. Schultz NMNH [printed]. The current condition and depository of the paratype are unknown.

\section{Type locality}

Ecuador: Guayas Province: Posorja ("Posoya").

Centris elegans grenadensis Cockerell, 1919

Fig. 4

Centris elegans grenadensis Cockerell, 1919: 186-187.

New junior synonym of C. (Centris) elegans Smith, 1874.

\section{Type data}

This subspecies was described based on a single male specimen collected by the American naturalist Herbert Huntington Smith (1851-1919) in Grenada, Lesser Antilles. Between 1890 and 1895, Smith spent much of his time in the employment of the West Indian Commission of the Royal Society in making collections in some of the Windward Islands of the West Indies (Saint Vincent and the Grenadines, and Trinidad and Tobago) (Holland 1919).

The holotype (Fig. 4) is housed at NMNH and has the following data label: Grenada W.I. H. H. Smith. [printed] 9 [handwritten] $\backslash$ Centris elegans grenadensis Ck1l. Type. [handwritten] \yellow label] USNM ENT 00534197 [barcode] [printed] $\backslash$ DO NOT REMOVE SI DB Reference Not a property tag T. Schultz NMNH [printed].

\section{Type locality}

Lesser Antilles: Grenada.

\section{Comment}

Centris elegans grenadensis only differs from $C$. elegans by the lighter hairs on hind legs and mesoscutellum (Fig 3B). At NMNH, there were found three males of C. elegans, with dark hairs on legs
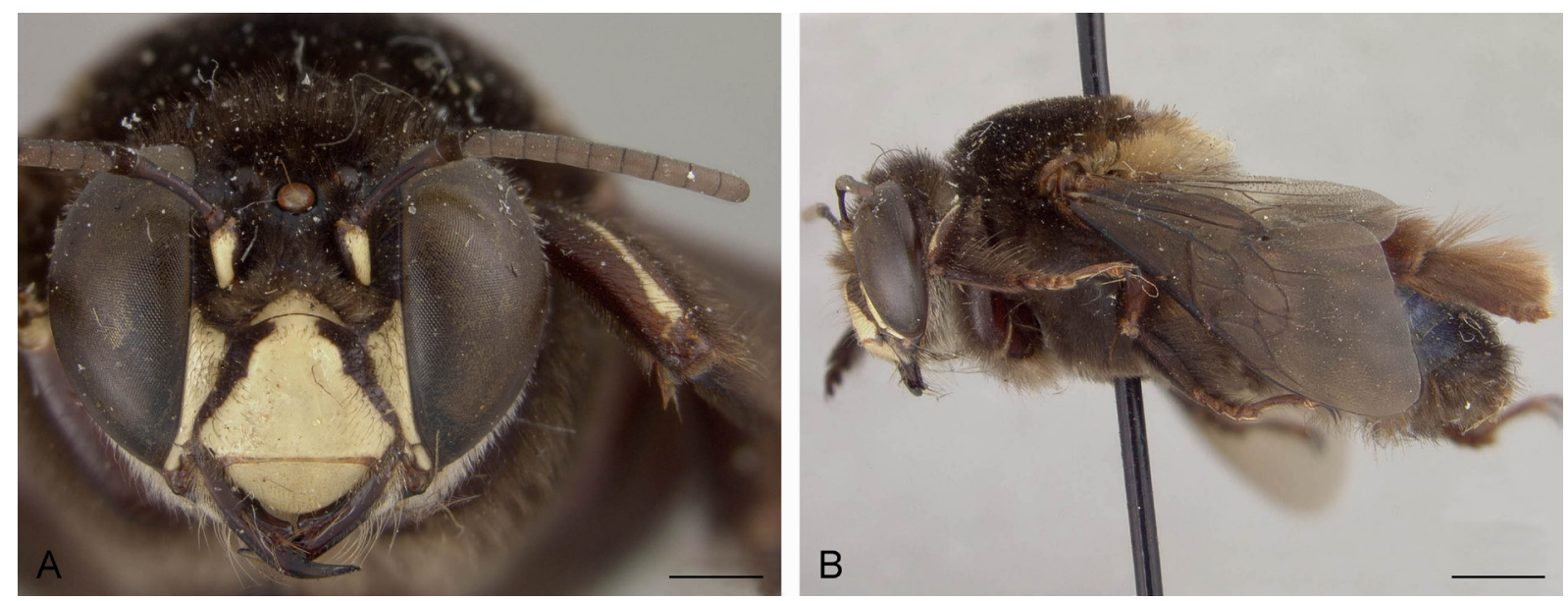

Fig. 4. Centris elegans grenadensis Cockerell, 1919, holotype, $ð$ (NMNH; USNM ENT 00534197). A. Frontal view. B. Habitus, lateral view. Scale bars: $A=1 \mathrm{~mm}$; $=2 \mathrm{~mm}$. 
and mesoscutellum, which according to their labels were collected along with the holotype of C. elegans grenadensis.

Centris inermis gualanensis Cockerell, 1912

Fig. 5

Centris inermis gualanensis Cockerell, 1912b: 568.

Junior synonym of C. (Centris) varia (Moure 1969; Roig-Alsina 2000).

\section{Type data}

This subspecies was described based on male and female specimens collected by W.P. Cockerell on February 22-23, 1912 at Gualán, Guatemala. Cockerell (1912b) mentioned that the type specimen was a female, but in the type series housed at NMNH, two specimens of that sex were found. Both specimens agree with the information provided in the original description but one of them was labeled by Cockerell himself as "type", while the other bears a label with the word "cotype". The holotype (Fig. 5) has the following data label: Gualan Guat Feb. 23, 191240 [handwritten] Centris inermis gualanensis Ckll. Type $q$ [handwritten] [red label] Type No. [printed] 23302 [handwritten] U.S.N.M. [printed] [yellow label] USNM ENT 00534199 [barcode] [printed] \ DO NOT REMOVE SI DB Reference Not a property tag T. Schultz NMNH [printed]. The female paratype has the following data label: Gualan; Guat Feb. 23-12[handwritten] Centris inermis gualanensis Ckll. cotype 9 [handwritten] $\backslash$ Paratype No [printed] 23302 [handwritten] USNM [printed] $\backslash$ Centris [printed] inermis Friese $q$ red phase [handwritten] det Snelling [printed] ' 82 [handwritten]. The male paratype has the following data label: Gualan. Guat Feb. 22-12191240 [handwritten] $\backslash$ Centris inermis gualanensis Ckll. cotype $\widehat{\diamond}$ [handwritten] $\backslash$ Paratype [printed] 23302 [handwritten] USNM [printed] $\backslash$ Centris [printed] inermis Friese $q$ red phase [handwritten] det Snelling [printed] '82 [handwritten].

\section{Type locality}

Guatemala: Zacapa Department: Gualán.
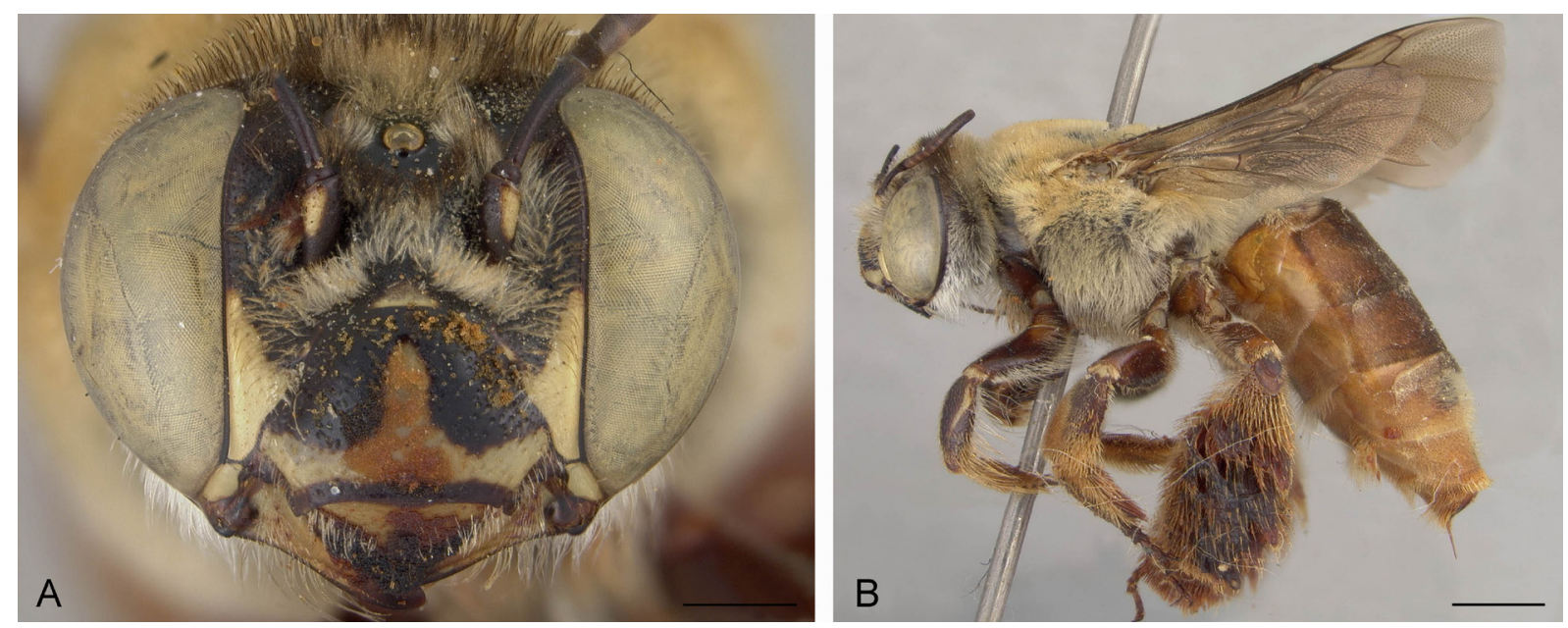

Fig. 5. Centris inermis gualanensis Cockerell, 1912, holotype, q (NMNH; USNM ENT 00534199). A. Frontal view. B. Habitus, lateral view. Scale bars: $A=1 \mathrm{~mm} ; \mathrm{B}=2 \mathrm{~mm}$. 


\section{Comment}

This subspecies was synonymized with $C$. inermis Friese, 1899 (Moure 1969). Subsequently, $C$. inermis was cited in the synonymy of $C$. varia by Roig-Alsina (2000).

\section{Centris inermis pallidifrons Cockerell, 1949}

Fig. 6

Centris inermis pallidifrons Cockerell, 1949: 479.

Junior synonym of C. (Centris) varia (Snelling 1966; Moure 1969).

\section{Type data}

This subspecies was described based on an apparently large series of males collected by Wilmatte Porter Cockerell and Adan Rivera at Zamorano and Tegucigalpa on flowers of Duranta plumieri Jacq. (Verbenaceae). Cockerell (1949) mentioned the type specimen was numbered "58887" but in the $\mathrm{NMNH}$, two males with this number were found. One of them bears a label with the word "type" and the other is labeled "cotype". The holotype (Fig. 6) has the following data label: Zamorano Honduras Feb. 8 [handwritten] $\backslash$ Mrs. [?] Williams [handwritten] $\backslash 180$. [handwritten] $\backslash$ Centris inermis pallidifrons Ckll type. [handwritten] [red label] Type No [printed] 58887 [handwritten] USNM [printed] [yellow label] USNM ENT 00534207 [barcode] [printed] \\ DO NOT REMOVE SI DB Reference Not a property tag T. Schultz NMNH [printed]. The male paratype has the following data label: 180 [printed] Zamorano Honduras Feb. 2 [handwritten] $\backslash$ Centris inermis pallidifrons Ckll cotype [handwritten] [red label] Paratype No [printed] 58887 [handwritten] USNM [printed] $\backslash$ C. (Centris) i. gualanensis $\underline{\text { Ckll. }}$ [handwritten] Det. J.S. Moure 19 [printed] 57 [handwritten].

\section{Type locality}

Honduras: Francisco Morazán Department: Zamorano.

\section{Comment}

Snelling (1966) proposed the synonymy between this subspecies and C. inermis gualanensis. Moure (1969) synonymized both subspecies, along with C. robusta, with C. inermis. Later, Roig-Alsina (2000) cited $C$. inermis in the synonymy of $C$. varia.
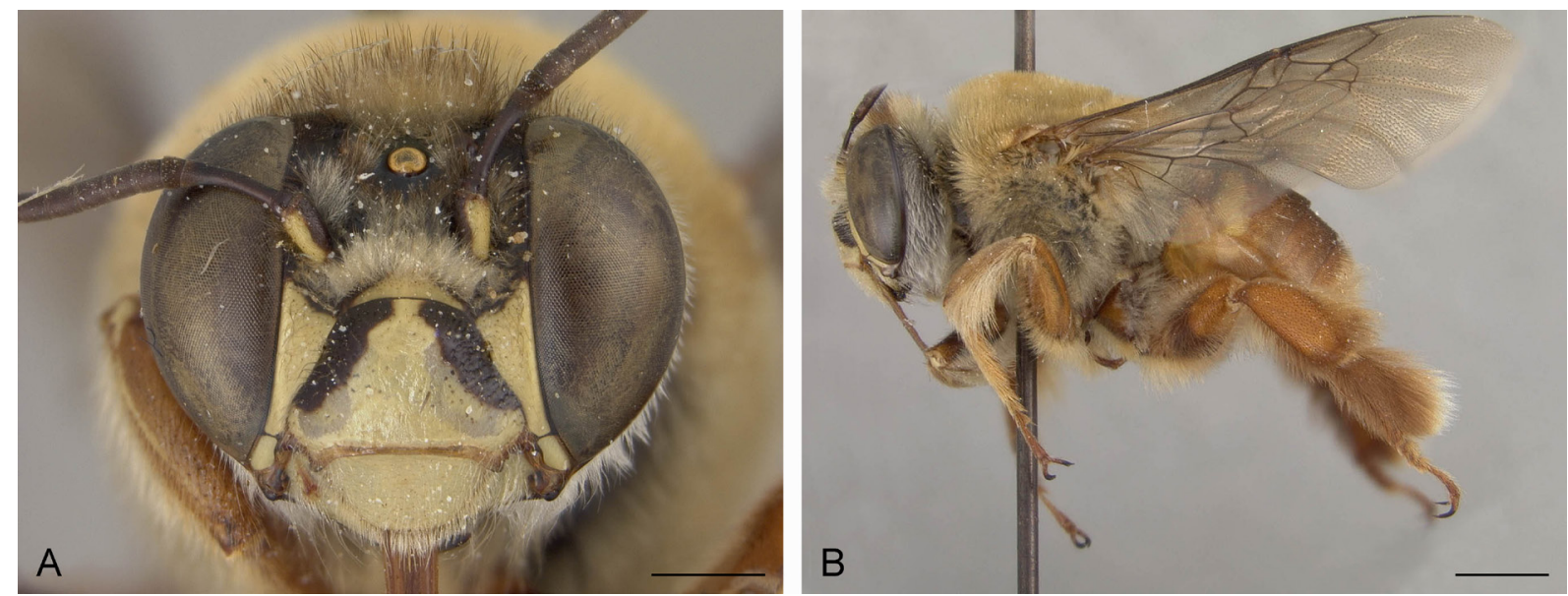

Fig. 6. Centris inermis pallidifrons Cockerell, 1949, holotype, đ̊ (NMNH; USNM ENT 00534207). A. Frontal view. B. Habitus, lateral view. Scale bars: $A=1 \mathrm{~mm} ; \mathrm{B}=2 \mathrm{~mm}$. 
Centris lepeletieri Cockerell, 1912

Centris lepeletieri Cockerell, 1912c: 140.

Junior synonym of C. (Centris) haemorrhoidalis (Fabricius, 1775) (Moure 1960).

\section{Type data}

Cockerell (1912c) recognized the existence of two species similar to each other, which would have been identified as $C$. haemorrhoidalis. According to him, the name $C$. haemorrhoidalis would be applied to Jamaican specimens where males have the first four terga and the anterior half of the fifth metallic blue, while females have the first four terga metallic blue and the rest reddish. Cockerell mentioned that the females from Santo Domingo, Dominican Republic identified by Lepeletier (1841) as $C$. haemorrhoidalis would correspond to a different species, since they have only the first three terga blue, proposing for them the name C. lepeletieri. Cockerell (1912c) was correct in indicating the existence of two similar species. However, C. lepeletieri was described based on specimens that correspond to the true $C$. haemorrhoidalis. The Jamaican species was described several decades later under the name $C$. dirrhoda Moure, 1960.

One of the females studied by Lepeletier (1841) was found at OUMNH and is here designated the lectotype of Centris lepeletieri. The specimen has the following data label: * Du [handwritten] Centris haemorrhoidalis Fabr Sto Domingo +.

\section{Type locality}

Dominican Republic: Distrito Nacional Province: Santo Domingo (“Saint-Domingue”).

\section{Comment}

This species was correctly interpreted by Moure (1960), who cited it in the synonymy of C. haemorrhoidalis.

Centris robusta Cockerell, 1949

Fig. 7

Centris (Rhodocentris) robusta Cockerell, 1949: 478-479.

Junior synonym of C. (Centris) varia (Moure 1969; Roig-Alsina 2000).

\section{Type data}

This species was described based on a single male specimen collected by Cockerell's wife at Zamorano on February 8. The holotype (Fig. 7) is housed at NMNH and has the following data label: Zamorano Honduras Feb.8 W.P.Ckll [handwritten] $\backslash 180$ [handwritten] $\backslash$ Centris wilmattae $\underline{\text { Ckll Type [handwritten] }}$ [red label] Type No [printed] 58886 [handwritten] USNM [printed] $\backslash$ Centris robusta Ck.- Type (wilmattae preocc.) [handwritten] \yellow label] USNM ENT 00534211 [barcode] [printed] $\backslash$ DO NOT REMOVE SI DB Reference Not a property tag T. Schultz NMNH [printed].

\section{Type locality}

Honduras: Francisco Morazán Department: Zamorano.

\section{Comments}

Cockerell considered describing C. robusta under the name "C. wilmattae", as an homage to his second wife. However, this name had already been used by Cockerell (1926a) himself for a species described 
from Arequipa, southern Peru (see below). Moure (1969) synonymized C. robusta with C. inermis. Snelling (1984) newly proposed this synonymy, apparently ignoring Moure's paper. Later, Roig-Alsina (2000) cited C. inermis in the synonymy of C. varia.
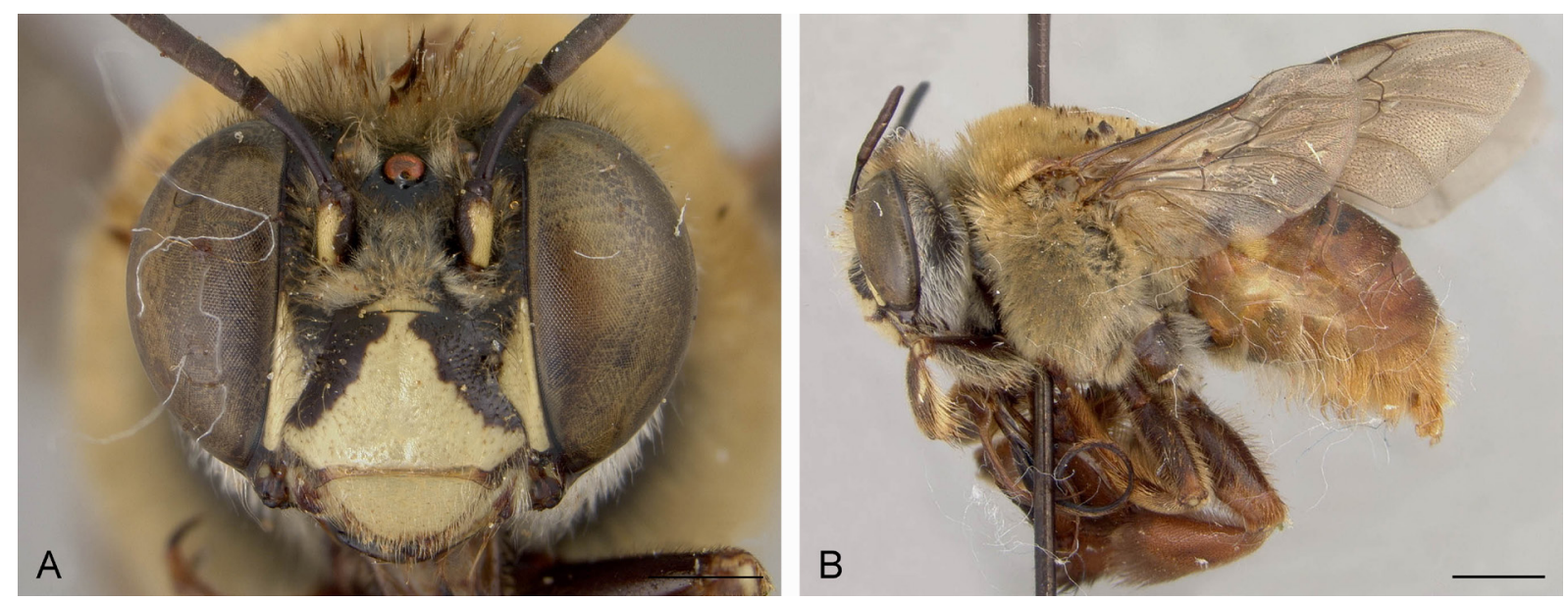

Fig. 7. Centris robusta Cockerell, 1949, holotype, $\widehat{~}($ NMNH; USNM ENT 00534211). A. Frontal view. B. Habitus, lateral view. Scale bars: $A=1 \mathrm{~mm} ; B=2 \mathrm{~mm}$.

Centris rufulina Cockerell, 1937 nom. rev.

Centris rufulina Cockerell, 1937a: 1-2.

\section{Type data}

This species was described based on a single male specimen collected by John Ogilvie at Waranama, Guyana, on November 10, 1936. The holotype is housed at AMNH under the code "acc. 34970" and has the following data label: Nov. 10.J.O. [handwritten] $\backslash$ Waranama.G., Nov. 1936 Ogilvie, Coll. [printed]

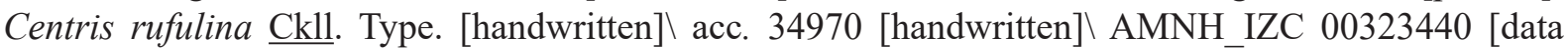
matrix code] [printed].

\section{Type locality}

Guyana: Waranama.

\section{Comment}

This species was cited as a junior synonym of $C$. varia (Moure et al. 2007), but it is actually a different species. Centris rufulina is only known from the type specimen and differs from $C$. varia, among other characters, by the shape of the third mandibular tooth (truncate in C. rufulina, acute in C. varia).

\section{Centris versicolor vincentana Cockerell, 1938}

Fig. 8

Centris versicolor vincentana Cockerell, 1938: 282-283.

Junior synonym of C. (Centris) versicolor (Fabricius, 1775) (Moure 1960).

\section{Type data}

This subspecies was described based on two males collected by J. Ogilvie at Saint Vincent, Lesser Antilles, on April 12, 1938. In the original description, Cockerell (1938) did not specify which male was 
the holotype or mentioned any data that could help to recognize it. However, Moure (1960) mentioned the type of this species was numbered 54853. In the NMNH, both specimens cited by Cockerell were found, with the number mentioned by Moure (1960), one bearing a label "type" and the other "cotype". The holotype (Fig. 8) has the following data label: St. Vincent 12.4.38 J.O. [handwritten] Centris versicolor vincentana Ckll Type. [handwritten] [red label] Type No 54853 [handwritten] USNM [printed] [yellow label] USNM ENT 00534218 [barcode] [printed] \ DO NOT REMOVE SI DB Reference Not a property tag T. Schultz NMNH [printed]. The male paratype has the following data label: St. Vincent B.W.I. 12.4.38 (J. Ogilvie) [handwritten] $\backslash$ Centris versicolor vincentana Ckll cotype [handwritten] $[$ red label] Paratype No 54853 [handwritten] USNM [printed]. Both specimens are in good condition.

\section{Type locality}

Lesser Antilles: Saint Vincent and the Grenadines: Saint Vincent Island.
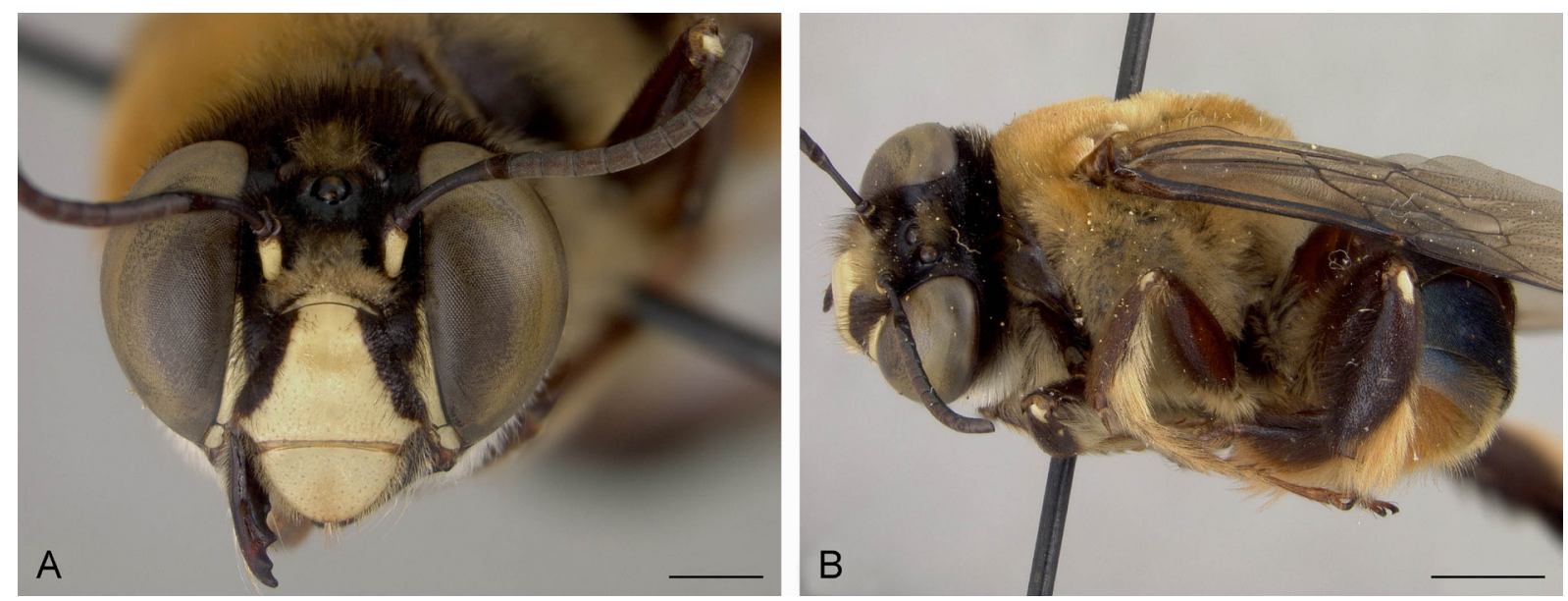

Fig. 8. Centris versicolor vincentana Cockerell, 1938, holotype, ô (NMNH; USNM ENT 00534218). A. Frontal view. B. Habitus, lateral view. Scale bars: $A=1 \mathrm{~mm} ; \mathrm{B}=2 \mathrm{~mm}$.

Subgenus Centris (Hemisiella) Moure, 1945

Centris barbadensis Cockerell, 1939

Centris barbadensis Cockerell, 1939: 142.

\section{Type data}

This species was described based on an undetermined number of specimens of both sexes collected by J. Ogilvie at Barbados. Cockerell (1939) mentioned that the type of the species was a male. A male specimen belonging to the type series is currently housed at NHMUK and was labeled as type by Cockerell himself. Another male of the type series was found at NMNH and was labeled by Cockerell as cotype. The female specimen mentioned in the original description was not found. The male holotype housed at NHMUK has the following data label: [circular label with red-rimmed margin] Type [printed] $\backslash$ B.M. TYPE Hym. [printed] 17B.928 [handwritten] $\backslash$ Centris barbadensis Ckll. Type [handwritten] $\backslash$ Barbados. 27.4.38. (J. Ogilvie) [handwritten] Type in Banks Coll. [printed]. The male paratype housed at NMNH has the following data label: Barbados. 27.4.38. (J. Ogilvie) [handwritten] $\backslash$ Centris barbadensis $\underline{\text { Ckll. }}$ cotype [handwritten] $\backslash$ Paratype [printed] 54874 [handwritten] USNM [printed]. 


\section{Type locality}

Lesser Antilles: Barbados.

\section{Comment}

Moure et al. (2007) erroneously mentioned that the type series was composed of female syntypes.

Centris geminata Cockerell, 1914 nom. rev.

Fig. 9

Centris nitida geminata Cockerell, 1914: 315-316.

\section{Type data}

Cockerell described this subspecies apparently based on a single female specimen collected by the American entomologist and naturalist Charles Thomas Brues (1879-1955), specialist on Hymenoptera, Diptera and on insect diet (Salt 1955), during a trip to South America. Moure et al. (2007) indicated that it was described from syntypes. Nevertheless, only a single female with original Cockerell's label of "type" was found at NMNH. Due to the lack of evidence on the existence of more type specimens and the impossibility to deduce this fact from the original description, the female housed at NMNH is here interpreted as holotype, taking into account the information of the Cockerell's own label. The specimen (Fig. 9) has the following data label: Guayaquil. Ecuador, May-June 1913. C. T. Brues [printed] [red label] Type No [printed] 54855 [handwritten] USNM [printed] \entris nitida geminata Ckll Type [handwritten] [yellow label] USNM ENT 00534196 [barcode] [printed] \ DO NOT REMOVE SI DB Reference Not a property tag T. Schultz NMNH [printed].

\section{Type locality}

Ecuador: Guayas Province: Guayaquil.

\section{Comment}

This species was mistakenly proposed as a junior synonym of C. facialis Mocsáry, 1899 (Rasmussen \& Vivallo 2014), a species superficially similar. The study of large series of both species allowed to revert the proposed synonymy and to consider both as valid species. Females of $C$. geminata and $C$. facialis differ in the coloration of the prepygidial fimbriae, yellowish in the former and dark brown or blackish in
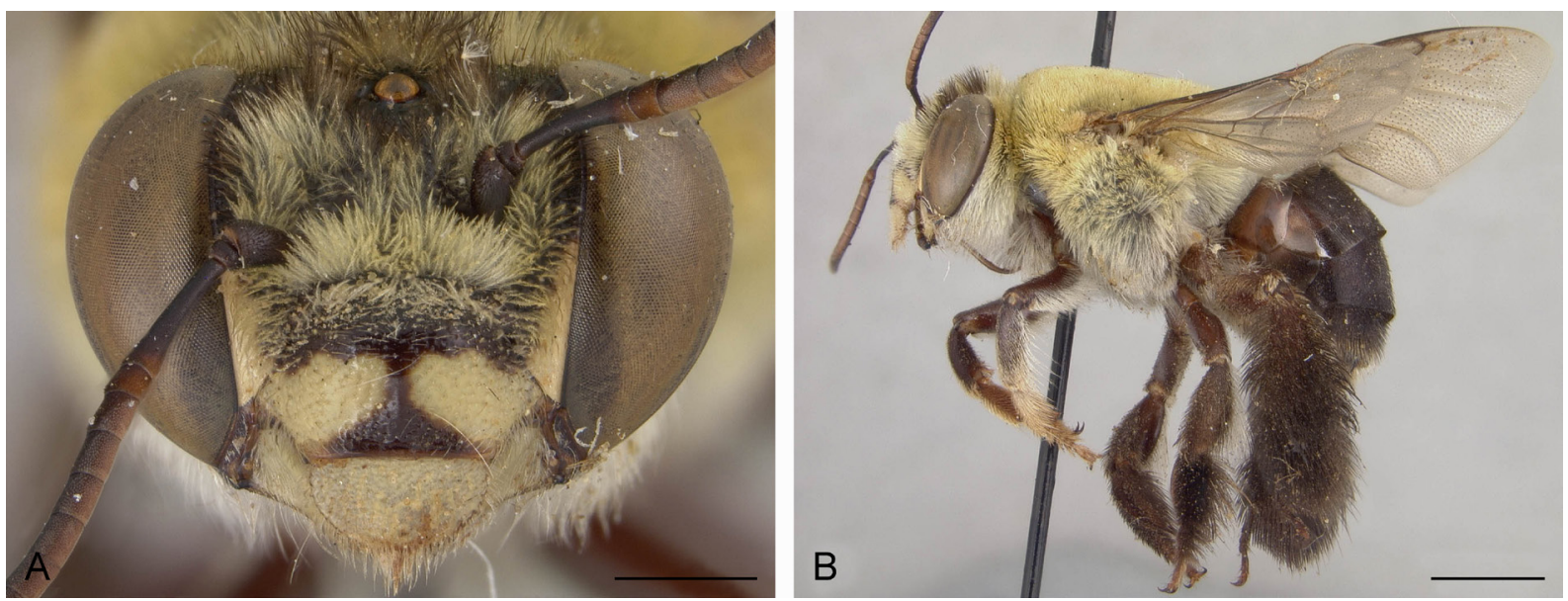

Fig. 9. Centris nitida geminata Cockerell, 1914, holotype, ㅇ (NMNH; USNM ENT 00534196). A. Frontal view. B. Habitus, lateral view. Scale bars: $A=1 \mathrm{~mm} ; \mathrm{B}=2 \mathrm{~mm}$. 
the latter species. The males of both species differ in the size and pubescence of the hind femur (slightly larger than the hind tibia and covered by whitish pubescence on the dorsal surface in $C$. geminata; evidently larger than the hind tibia and covered completely by dark brown to black pubescence in C. facialis).

\section{Centris lanipes ogilviei Cockerell, 1936}

Centris lanipes ogilviei Cockerell, 1936: 632.

Junior synonym of C. (Hemisiella) nigrescens Lepeletier, 1841 (Vivallo 2019a).

\section{Type data}

According to the original description, Cockerell proposed this subspecies based on two females collected by J. Ogilvie at Onverwagt, Guyana, on January 10, 1936. The type specimen (NHMUK, examined) has the following data label: [white circular label with red margin] Type [printed] $\backslash$ Centris lanipes ogilviei Ckll Type [handwritten] $\backslash$ Onverwagt B. Guiana Jan 10’36 (J. Ogilvie) [handwritten] $\backslash$ B. M. Type HYM 17B.920 [handwritten]. The type is in good condition and is coded NHMUK010812613 in the NHMUK data portal.

\section{Type locality}

Guyana: Onverwagt.

Centris lanipes subtarsata Cockerell, 1949

Fig. 10

Centris (Rhodocentris) lanipes subtarsata Cockerell, 1949: 476-477.

Junior synonym of C. (Hemisiella) trigonoides Lepeletier, 1841 (Snelling 1984).

\section{Type data}

Cockerell described this subspecies based on an undetermined number of male and female specimens collected on an adobe wall at San Francisco ranch near Zamorano, Honduras, on November 10. Although he mentioned that the type was from that locality, he failed to mention the sex of the specimen chosen.
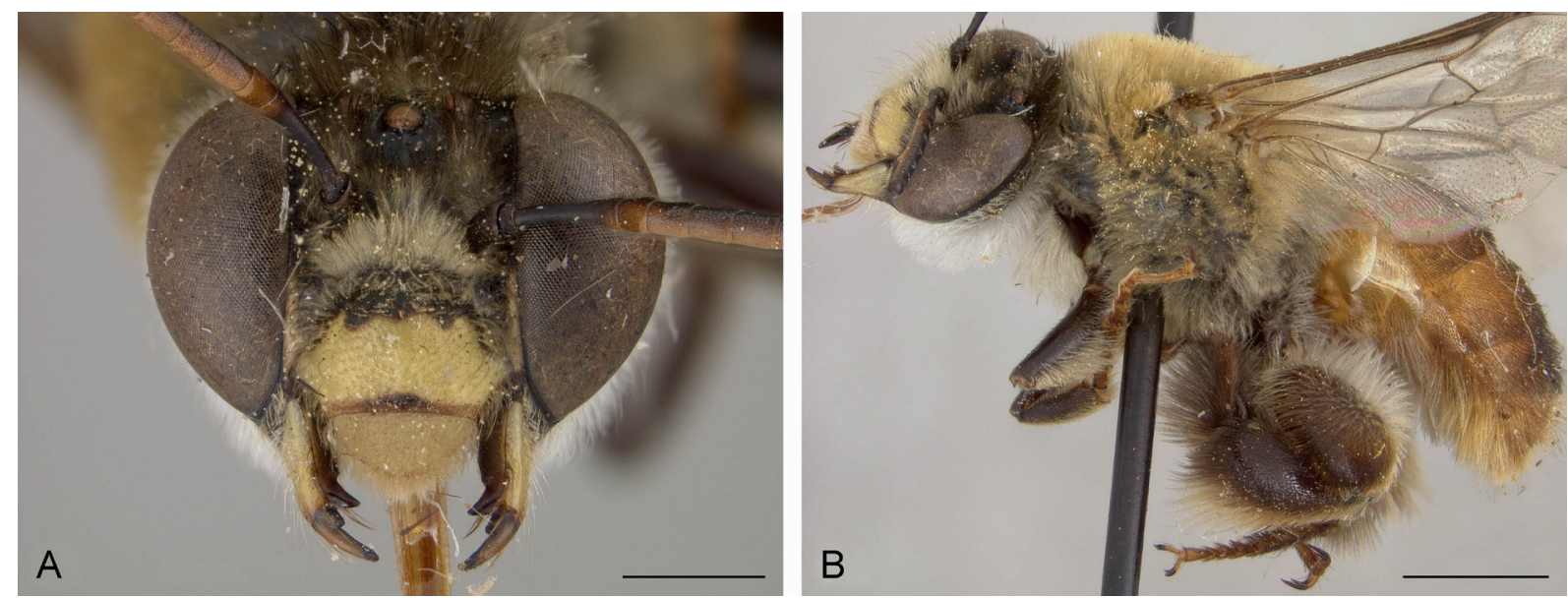

Fig. 10. Centris lanipes subtarsata Cockerell, 1949, holotype, đ̊ (NMNH; USNM ENT 00534216). A. Frontal view. B. Habitus, lateral view. Scale bars: $A=1 \mathrm{~mm} ; \mathrm{B}=2 \mathrm{~mm}$. 
At NMNH, a male specimen was found with original labels of Cockerell, one with the name of the new subspecies and the word "type", and the other indicating that it was collected at an adobe wall in San Francisco, on November 3 not 10 as Cockerell mentioned explicitly. In the same collection, a female collected by Cockerell was found that bears an original label of Cockerell that agrees exactly with the information provided in the original description, but mentions in Cockerell's handwriting "cotype". Both specimens have subtle inconsistencies on the information labels and no additional specimens of the type series were found at NMNH or in any other collection that contains Cockerell's types of Centris bees (AMNH, ANSP, CAS, NHMUK, OUMNH and ZMB). Despite the differences cited above, I am interpreting the male specimen as the holotype of the species, following the information on its label. The holotype (Fig. 10) has the following data label: [?] adobe wall S. Francisco finca Honduras Nov. 3 [handwritten] 3 [handwritten] $\backslash$ Centris lanipes subtarsata Ckll Type [handwritten] [red label] Type No [printed] 58884 [handwritten] USNM [printed] [yellow label] USNM ENT 00534216 [barcode] [printed] $\backslash$ DO NOT REMOVE SI DB Reference Not a property tag T. Schultz NMNH [printed]. The female paratype has the following data label: San Francisco finca Zamorano Honduras Nov 10 [handwritten]\2 [handwritten] Centris lanipes subtarsata Ckll cotype [handwritten] [red label] Allotype No. [printed] 58884 [handwritten] U.S.N.M. [printed]. The current condition and depository of any other possible paratype are unknown.

Cockerell also mentioned a male specimen collected in San José, Guatemala on December 22, 1946, by A. Pelén, probably Amador Pelén Cantoral (1923-2007), an former student and employee of the Escuela Agrícola Panamericana (Pitty 2008). It is not clear whether this specimen belonged to the type series, and unfortunately, it was not found during this research.

\section{Type locality}

Honduras: Francisco Morazán Department: Zamorano.

\section{Comment}

Moure et al. (2007) also interpreted the male specimen cited above as the holotype of this species.

Centris merrillae Cockerell, 1919

Fig. 11

Centris merrillae Cockerell, 1919: 191.

Junior synonym of C. (Hemisiella) nigrescens (Vivallo 2019a).

\section{Type data}

This species was described based on a single female specimen collected by the American limnologist and Amazon traveler Harriet Bell Merrill (1863-1915) during a research trip to South America. According to Rathbun (1911), she sold to the NMNH 500 specimens of insects collected during her expedition to Brazil, including probably the exemplar studied by Cockerell. The holotype (Fig. 11) is housed at NMNH and has the following data label: Manaos Brazil [printed] $\backslash$ Miss HBMerrill Collector [printed] Centris merrillae Ckll Type. [handwritten] [red label] Type No. [printed] 21655 [handwritten] U.S.N.M. [printed] \[yellow label] USNM ENT 00534204 [barcode] [printed] \ DO NOT REMOVE SI DB Reference Not a property tag T. Schultz NMNH [printed]. The holotype is in good condition.

\section{Type locality}

Brazil: Amazonas State: Manaus (“Manaos"). 

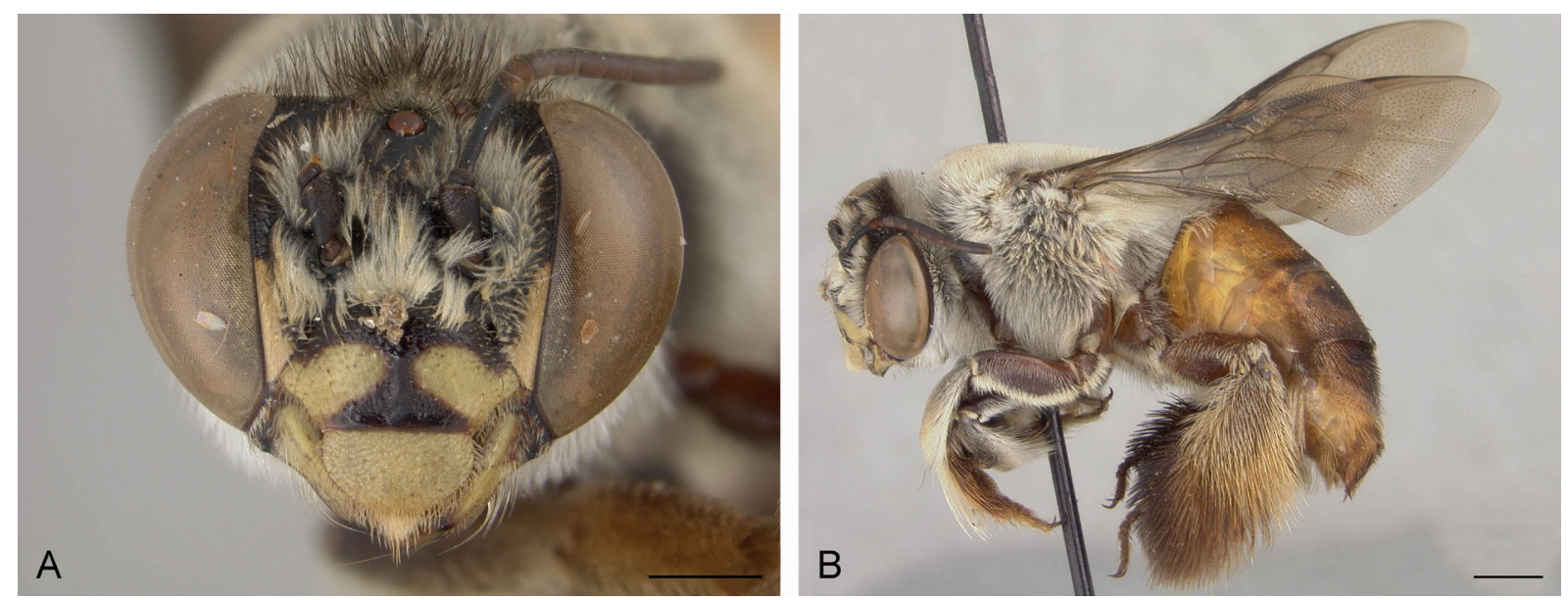

Fig. 11. Centris merrillae Cockerell, 1919, holotype, $q$ (NMNH; USNM ENT 00534204). A. Frontal view. B. Habitus, lateral view. Scale bars: $A=1 \mathrm{~mm} ; B=2 \mathrm{~mm}$.

\section{Centris rhodadelpha Cockerell, 1939}

Fig. 12

Centris rhodadelpha Cockerell, 1939: 142.

\section{Type data}

This species was described based on male and female specimens collected by J. Ogilvie at Barbados on April 25-26, 1938. Cockerell described both sexes of this species, but he did not indicate how many specimens of each sex he used. Apparently, the type series was composed of at least one male and two females, which were found at NMNH. The male was chosen as holotype. and it was labeled by Cockerell as such. The male holotype (Fig. 12) has the following data label: Barbados 26-4.38 (J. Ogilvie) [handwritten] $\backslash$ Centris rhodadelpha Ckll. Type [handwritten] [red label] Type No [printed] 54854 [handwritten] USNM [printed] \[yellow label] USNM ENT 00534209 [barcode] [printed] $\backslash$ DO NOT REMOVE SI DB Reference Not a property tag T. Schultz NMNH [printed]. The female paratype has the following data label: Barbados 25.4.38 (J. Ogilvie) [handwritten] Centris rhodadelpha $\underline{\text { Ckll. }}$ cotype [handwritten] [red label] Paratype [printed] 54854 [handwritten] USNM [printed]. The female
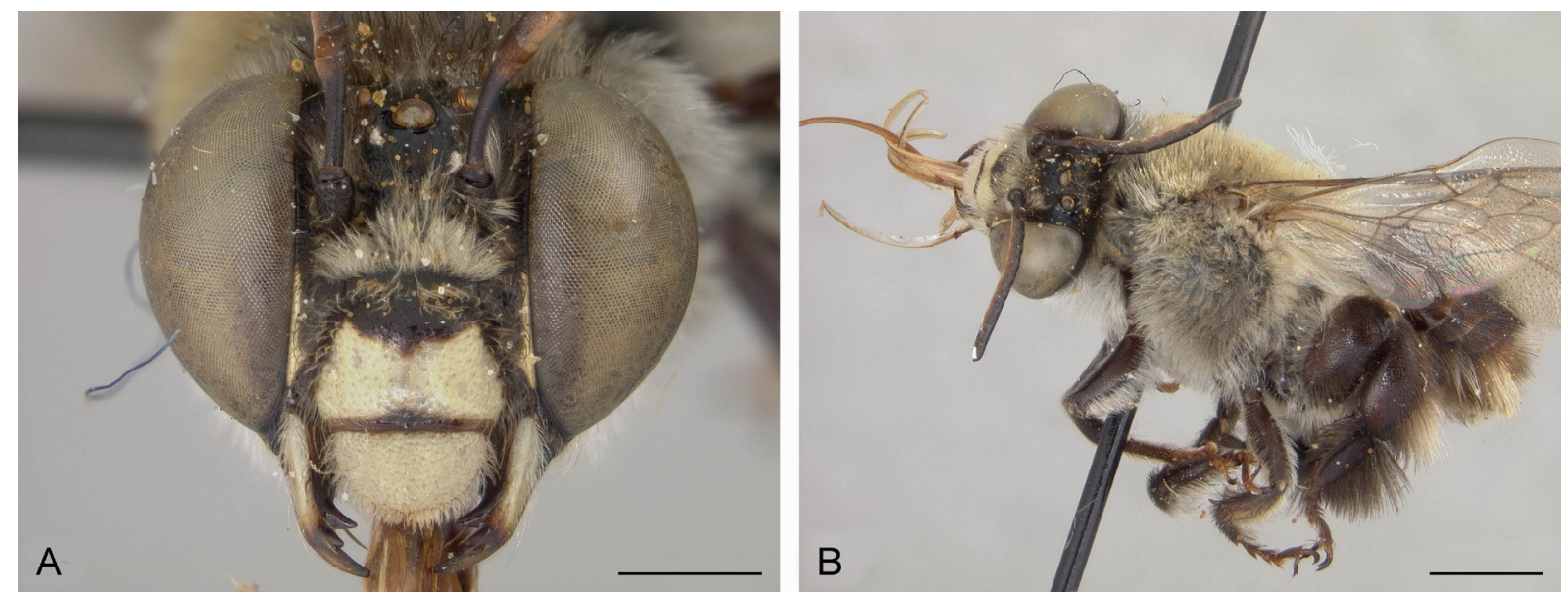

Fig. 12. Centris rhodadelpha Cockerell, 1939, holotype, ổ (NMNH; USNM ENT 00534209). A. Frontal view. B. Habitus, lateral view. Scale bars: $A=1 \mathrm{~mm} ; B=2 \mathrm{~mm}$. 
paratype has the following data label: Barbados 25.4.38 (J. Ogilvie) [handwritten] $\backslash$ Centris rhodadelpha Ckll. cotype [handwritten] [red label] Paratype No [printed] 54854 [handwritten] USNM [printed].

\section{Type locality}

Lesser Antilles: Barbados.

\section{Comment}

Moure et al. (2007) mentioned the sex of the holotype erroneously.

Centris ruae Cockerell, 1949

Fig. 13

Centris (Melanocentris) ruae Cockerell, 1949: 474-475.

New junior synonym of $C$. (Hemisiella) nitida Smith, 1874.

\section{Type data}

This species was described based on male and female specimens collected in Honduras. The female holotype was collected on March 30 at Escuela Agrícola Panamericana by Rua Williams, the wife of the American explorer and botanist Louis Otho Williams, who worked on the flora of Central America (Burger 1991). According to the original description, the type series was composed of another female specimen collected by Adan Rivera on April 8 and two males collected by Wilmatte P. Cockerell and Adan Rivera on January 28. The holotype (Fig. 13) is currently housed at NMNH and has the following data label: Zamorano Honduras March 30 Mrs. Williams [handwritten] Centris ruae Ckll Type [red label] Type No [printed] 58880 [handwritten] USNM [printed] [yellow label] USNM ENT 00534212 [barcode] [printed] $\backslash$ DO NOT REMOVE SI DB Reference Not a property tag T. Schultz NMNH [printed].

\section{Type locality}

Honduras: Francisco Morazán Department: Zamorano.
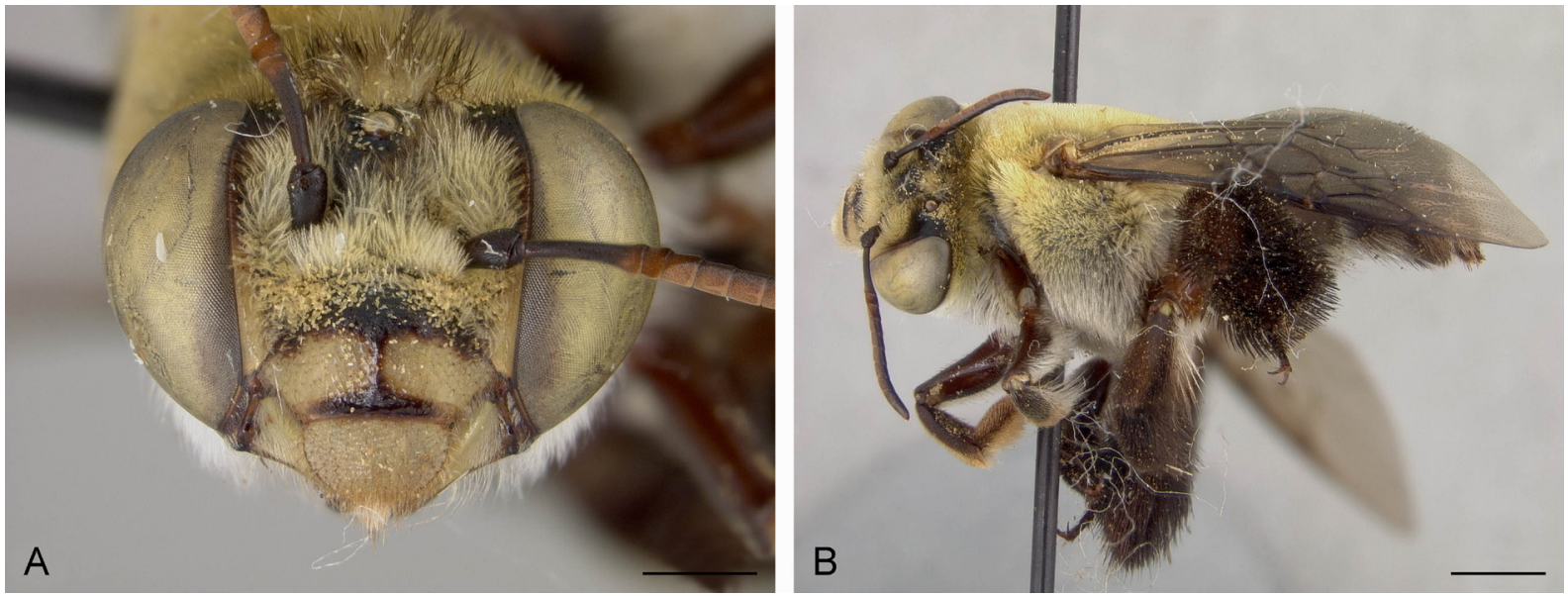

Fig. 13. Centris ruae Cockerell, 1949, holotype, $q$ (NMNH; USNM ENT 00534212). A. Frontal view. B. Habitus, lateral view. Scale bars: $A=1 \mathrm{~mm} ; B=2 \mathrm{~mm}$. 


\section{Comment}

Snelling (1984) mentioned, he studied the type specimen of C. ruae, considering it conspecific with C. transversa Pérez, 1905. It is not clear whether he studied the type of the latter species to propose the mentioned synonymy, but according to the information he cited in his article, apparently he did not, assuming the differences between both species as a result of variation. The study of both type specimens allows recognizing $C$. transversa and $C$. ruae as different species, and proposing the transfer of the latter from the synonymy of the former species to the synonymy of $C$. nitida.

Centris rufomaculata Cockerell, 1949

Fig. 14

Centris rufomaculata Cockerell, 1949: 476.

Junior synonym of C. trigonoides (Snelling 1984).

\section{Type data}

This species was described based on a single male specimen collected on February 7 at Zamorano, Honduras. The holotype (Fig. 14) is housed at NMNH and has the following data label: Zamorano Honduras Feb. 7. [handwritten] 30 [handwritten] Centris rufomaculata Ckll Type [handwritten] \red label] Type No [printed] 58883 [handwritten] USNM [printed] \ [yellow label] USNM ENT 00534213 [barcode] [printed] $\backslash$ DO NOT REMOVE SI DB Reference Not a property tag T. Schultz NMNH [printed].

\section{Type locality}

Honduras: Francisco Morazán Department: Zamorano.
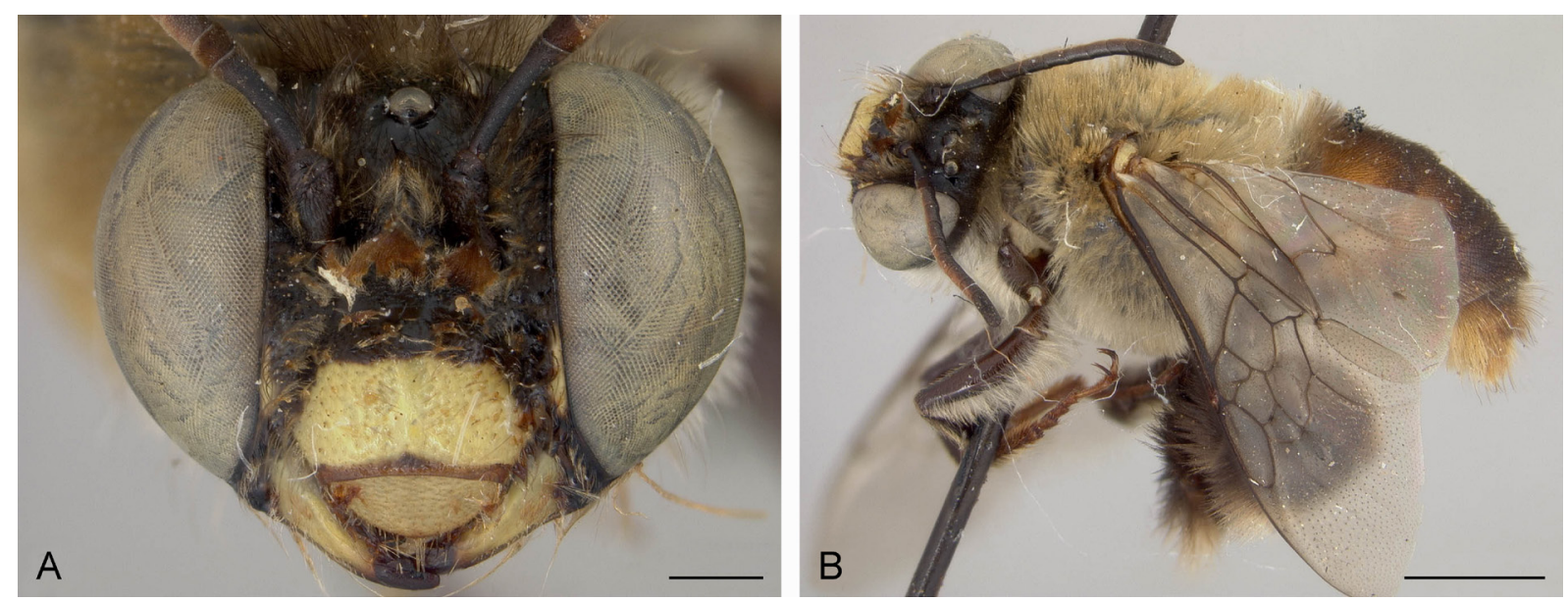

Fig. 14. Centris rufomaculata Cockerell, 1949, holotype, $\partial$ (NMNH; USNM ENT 00534213). A. Frontal view. B. Habitus, lateral view. Scale bars: $A=1 \mathrm{~mm} ; B=2 \mathrm{~mm}$.

Subgenus Centris (Heterocentris) Cockerell, 1899

Centris ceratocephala Cockerell, 1912

Centris ceratocephala Cockerell, 1912a: 45.

Junior synonym of C. (Heterocentris) bicornuta Mocsáry, 1899 (Moure et al. 2007). 


\section{Type data}

Cockerell (1912a) did not specify how many females he used to describe this species, but according to the labels of the type housed at AMNH, apparently he had only one specimen available collected by William Mann and Fred Baker in northern Brazil during the Stanford Expedition. This specimen is herein considered holotype, it is in good condition, with the following data label: Manaos, Brazil Mann

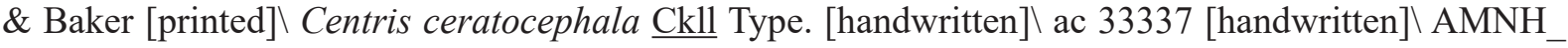
IZC 00323435 [data matrix code] [printed].

\section{Type locality}

Brazil: Amazonas State: Manaus (“Manaos").

\section{Comments}

Moure et al. (2007) were not able to find the depository of the holotype of this species. Centris bicornuta occurs from Mexico to Argentina (Snelling 1984; Roig-Alsina 2000). According to the accession book at the AMNH, the number 33337 was assigned to about 100 specimens that were sent from Cockerell's collection to the AMNH. This number is also present on the labels of the primary types of C. ceratocephala, C. euphenax, C. libertatis, C. maroniana and C. wilmattae (see below).

Centris durantae Cockerell, 1949

Fig. 15

Centris (Melanocentris) durantae Cockerell, 1949: 474.

Junior synonym of C. (Heterocentris) analis (Fabricius, 1804) (Michener 1954; Moure 1960).

\section{Type data}

This species was described based on a single male specimen collected by Wilmatte Cockerell on February 2, foraging on Duranta plumieri (Fabaceae). The holotype (Fig. 15) is currently housed at NMNH and has the following data label: 179a [?] [handwritten] ZZamorano on Duranta [?] Feb 2 W.P. Ckll [handwritten] $\backslash$ Centris durantae Ckll Type. [handwritten] [red label] Type No [printed] 58879 [handwritten] USNM [printed] [yellow label] USNM ENT 00534198 [barcode] [printed] \\ DO NOT REMOVE SI DB Reference Not a property tag T. Schultz NMNH [printed].
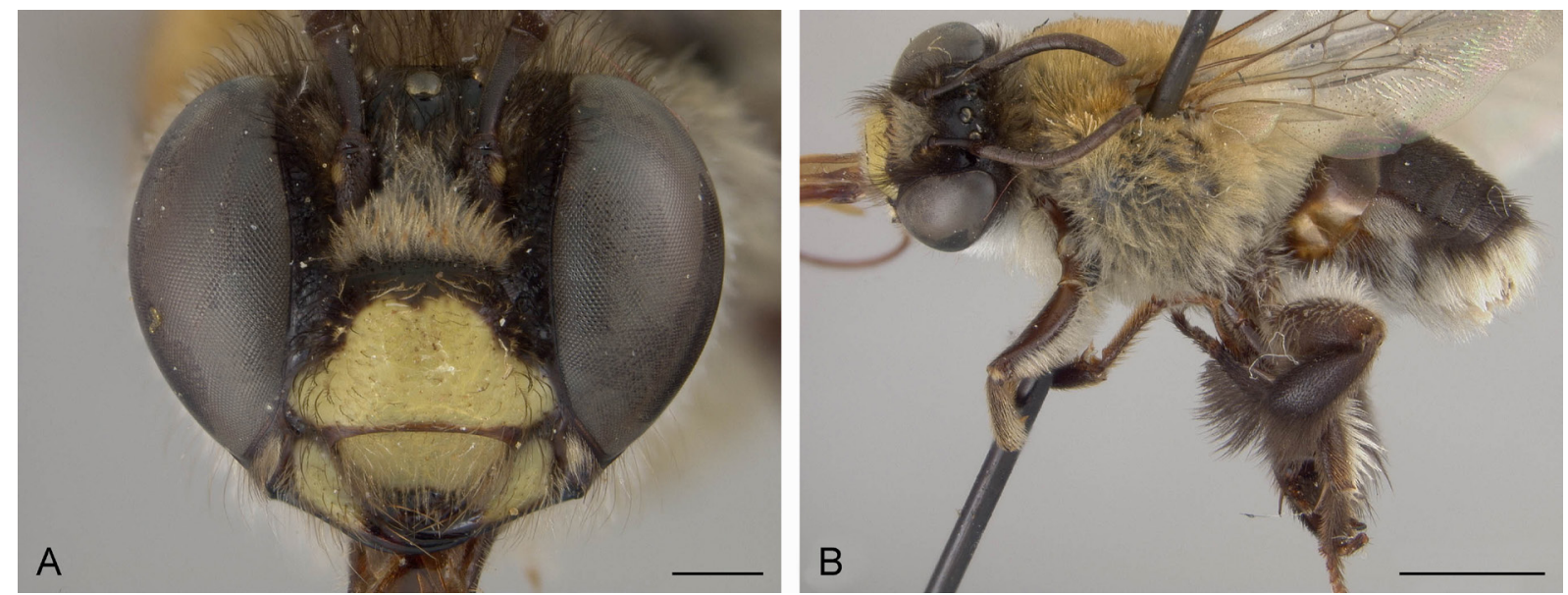

Fig. 15. Centris durantae Cockerell, 1949, holotype, ð (NMNH; USNM ENT 00534198). A. Frontal view. B. Habitus, lateral view. Scale bars: $A=1 \mathrm{~mm} ; \mathrm{B}=2 \mathrm{~mm}$. 


\section{Type locality}

Honduras: Francisco Morazán Department: Zamorano.

\section{Centris petreae Cockerell, 1949}

Fig. 16

Centris (Melanocentris) petreae Cockerell, 1949; 475.

Junior synonym of C. (Heterocentris) analis (Michener 1954; Moure 1960).

\section{Type data}

This species was described based on a single male specimen collected by Rua Williams in January at Zamorano, Honduras, foraging on Petrea voluvilis L. (Verbenaceae). The specimen (Fig. 16) is housed at NMNH and has the following data label: Zamorano Honduras Jan 11 Rua Williams [handwritten] 140 [handwritten] $\backslash$ Centris petreae Ckll type [handwritten] $\backslash$ [red label] Type No [printed] 58881 [handwritten] USNM [printed] [yellow label] USNM ENT 00534210 [barcode] [printed] \ DO NOT REMOVE SI DB Reference Not a property tag T. Schultz NMNH [printed].

\section{Type locality}

Honduras: Francisco Morazán Department: Zamorano.
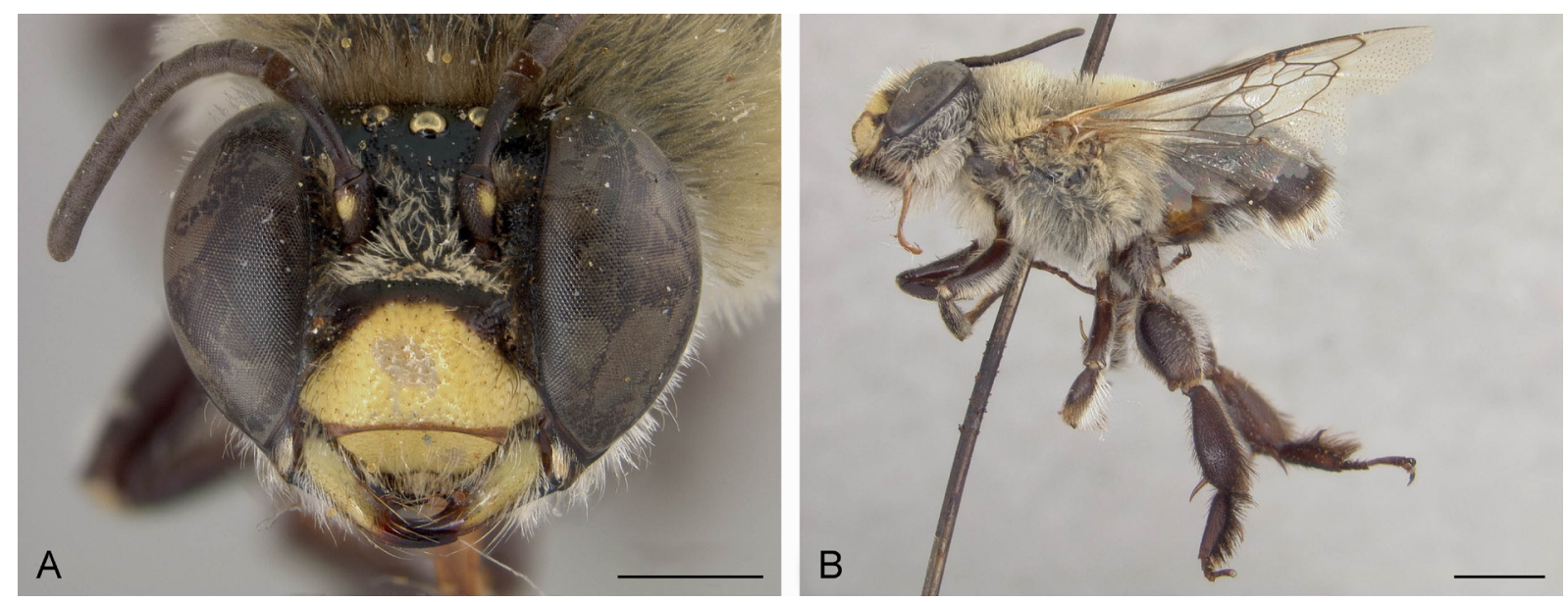

Fig. 16. Centris petreae Cockerell, 1949, holotype, ô (NMNH; USNM ENT 00534210). A. Frontal view. B. Habitus, lateral view. Scale bars: $A=1 \mathrm{~mm} ; B=2 \mathrm{~mm}$.

Centris petreae rufopicta Cockerell, 1949

Centris (Melanocentris) petreae rufopicta Cockerell, 1949: 475-476.

Junior synonym of $C$. (Heterocentris) analis (Michener 1954; Moure 1960).

\section{Type data}

Cockerell (1949) described this subspecies based on a single male specimen collected by Rua Williams on January 11 at Zamorano, Honduras, apparently along with the type specimen of $C$. petreae. The head of the type is detached and stored in a pinned plastic recipient. The specimen is housed at NMNH and has the following data label: [?]\Zamorano Honduras Jan. 11 Rua Williams [handwritten] Centris 


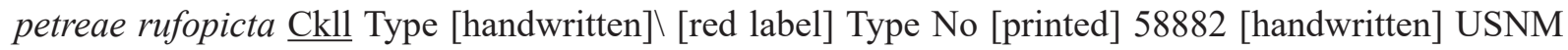
[printed].

\section{Type locality}

Honduras: Francisco Morazán Department: Zamorano.

\section{Comment}

Taxonomic decision for synonymy: Michener (1954) proposed C. durantae, C. petreae, C. petreae rufopicta and C. otomita Cresson, 1879 as junior synonyms of $C$. totonaca Cresson, 1879. Subsequently, Moure (1960) synonymized the latter species and C. minuta Mocsáry, 1899 with C. analis.

Centris semilabrosa (Cockerell, 1910) nom. rev.

Hemisia semilabrosa Cockerell, 1910: 142.

\section{Type data}

This species was described based on a single female specimen collected by William F.H. Rosenberg in an undetermined locality in Ecuador. The holotype was examined and is currently housed at NHMUK bearing the following data label: [circular label with red-rimmed margin] Type [printed] Ecuador. Rosenberg. 99-104- [printed] $\backslash$ Hemisia semilabrosa Ck11 Type. [handwritten] $\backslash$ B.M. TYPE HYM. [printed] 17B 911. [handwritten].

\section{Type locality}

Ecuador.

\section{Comment}

Centris triangulifera nom. rev., C. labrosa Friese, 1899 and C. terminata Smith, 1874 belong to a complex internal lineage of $C$. (Heterocentris), which apparently also includes some undescribed species from Central and South America. Unfortunately, a taxonomic revision of this subgenus is not currently available, so the real identity of these species is unclear. Centris labrosa and C. triangulifera are different species, but the type specimen of the latter is almost identical with that of C. semilabrosa, which was proposed as a junior synonym of $C$. terminata (see Moure et al. 2007). Considering the complexity of the problem, I propose to remove $C$. triangulifera (see below) from the synonymy of C. labrosa - a synonymy proposed by Snelling (1984), who apparently did not study the type specimens of the latter species - and C. semilabrosa from the synonymy of $C$. terminata, at least until a taxonomic revision of this group is made that allows to distinguish the limits between each of these species.

Centris triangulifera Cockerell, 1949 nom. rev.

Fig. 17

Centris (Rhodocentris) triangulifera Cockerell, 1949: 477.

\section{Type data}

Cockerell (1949) did not mention the number of females he studied to describe this species. According to the label of the type specimen examined at NMNH, apparently he had only a single specimen collected by Adan Rivera on January 30 at Zamorano, Honduras. The holotype (Fig. 17) has the following data label: Zamorano Honduras Jan 30 Adan R [handwritten] 126. [handwritten] $\backslash$ Centris triangulifera Ckll Type. [handwritten] [red label] Type No [printed] 58885 [handwritten] USNM [printed] [yellow label] 
USNM ENT 00534217 [barcode] [printed] $\backslash$ DO NOT REMOVE SI DB Reference Not a property tag T. Schultz NMNH [printed].

\section{Type locality}

Honduras: Francisco Morazán Department: Zamorano.
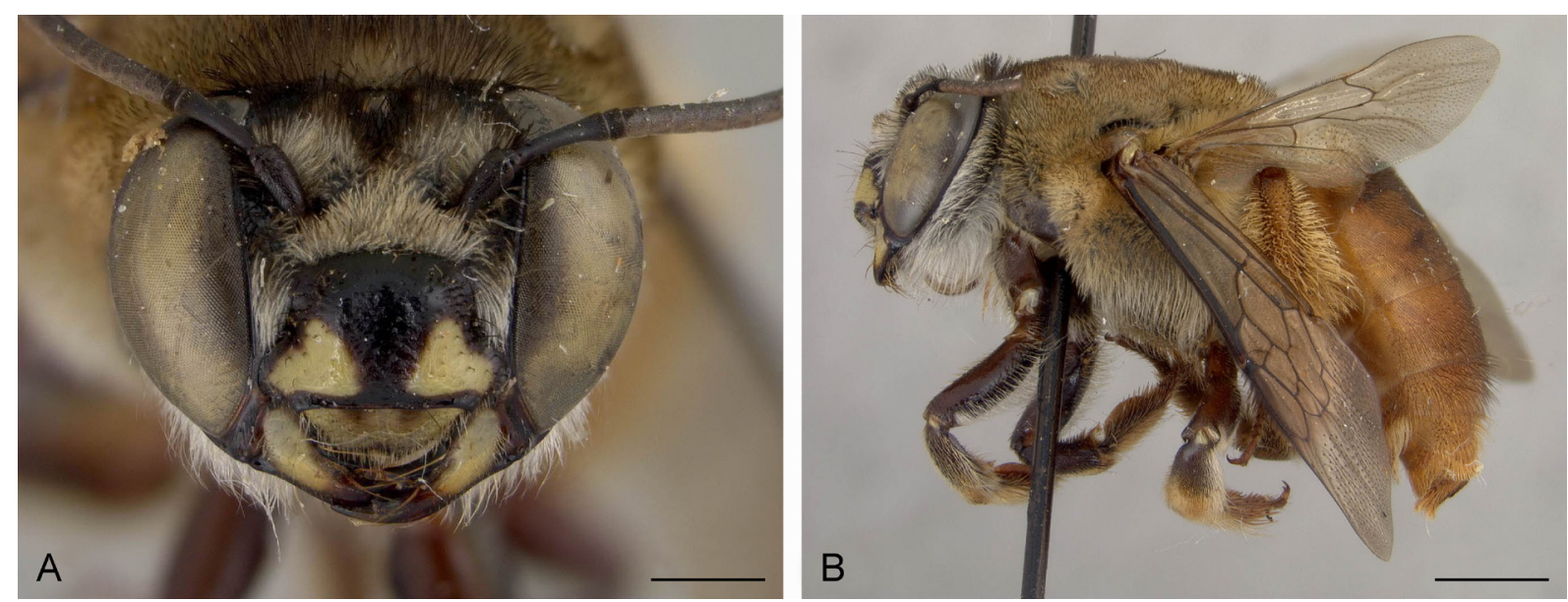

Fig. 17. Hemisia triangulifera Cockerell, 1949, holotype, $q$ (NMNH; USNM ENT 00534217). A. Frontal view. B. Habitus, lateral view. Scale bars: $A=1 \mathrm{~mm} ; \mathrm{B}=2 \mathrm{~mm}$.

Subgenus Centris (Melanocentris) Friese, 1901

Centris caurensis Cockerell, 1919

Fig. 18

Centris fusciventris caurensis Cockerell, 1919: 189.

\section{Type data}

This species was described based on a single male specimen collected by the American ornithologist and entomologist Melbourne Armstrong Carriker (1879-1965). He traveled extensively throughout South
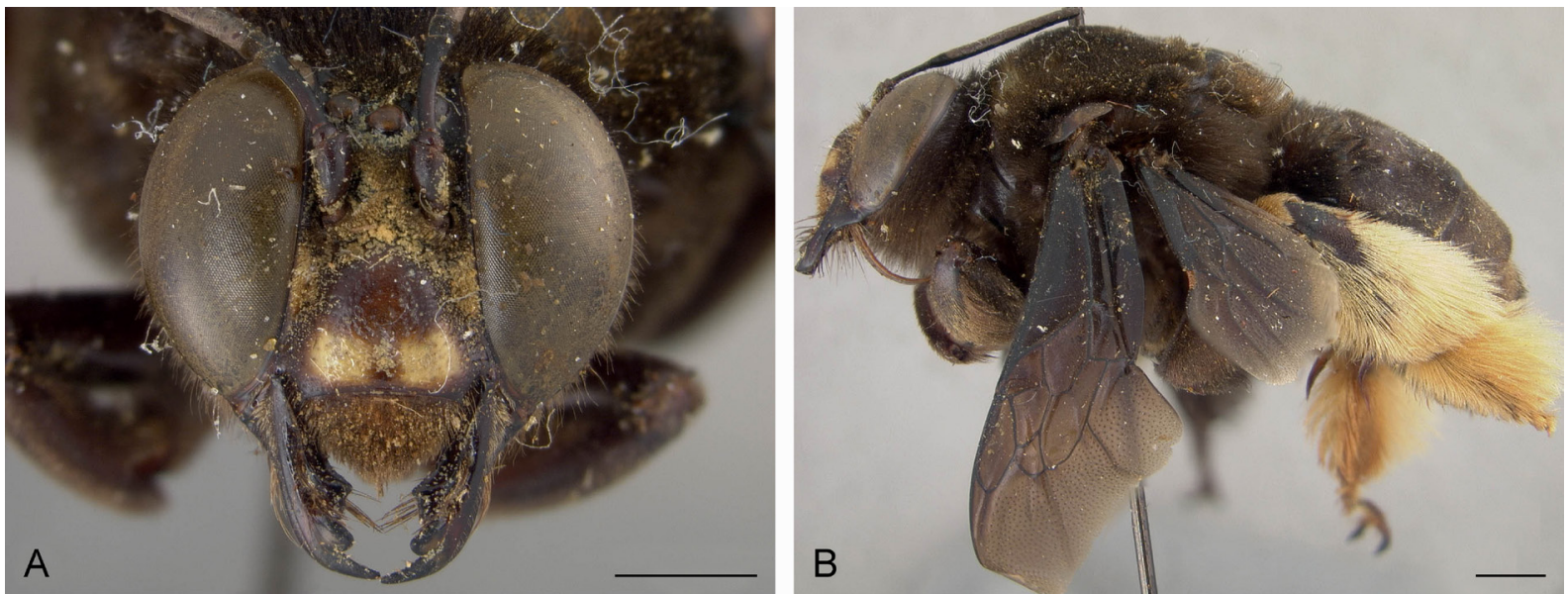

Fig. 18. Centris fusciventris caurensis Cockerell, 1919, holotype, $ð$ (NMNH; USNM ENT 00534189). A. Frontal view. B. Habitus, lateral view. Scale bars: A =1 mm; B $=2 \mathrm{~mm}$. 
America and collected specimens for some of the most renowned American museums of natural history, like the AMNH, the NMNH and the Natural History Museum of Los Angeles County. The specimens studied by Cockerell were collected during a trip to Venezuela between 1909 and 1910 (Smithsonian Institution Archives 2019). The holotype (Fig. 18) is currently housed at NMNH and has the following data label: Rio Mato Caura Dist Venez [printed] X.09 [handwritten] $\backslash$ MACarriker collector [printed] Centris fusciventris var. caurensis Ckll. Type [handwritten] $\backslash$ [red label] Type No [printed] 21653 [handwritten] U.S.N.M. [printed] [yellow label] USNM ENT 00534189 [barcode] [printed] \ DO NOT REMOVE SI DB Reference Not a property tag T. Schultz NMNH [printed].

\section{Type locality}

Venezuela: Bolívar State: Rio Mato (“Caura district, Rio Mato”).

Centris fusciventris matoensis Cockerell, 1919

Fig. 19

Centris fusciventris matoensis Cockerell, 1919: 189-190.

New junior synonym of C. (Melanocentris) caurensis Cockerell, 1919.

\section{Type data}

As for Centris caurensis, the single male specimen used by Cockerell (1919) to describe this species was also collected by Melbourne Carriker in the same locality. The holotype (Fig. 19) is housed at NMNH and has the following data label: Rio Mato Caura Dist Venez [printed] X.09 [handwritten] $\backslash$ MACarriker collector [printed] $\backslash$ Centris fusciventris var. matoensis Ckll Type [handwritten] [red label] Type No. [printed] 21654 [handwritten] U.S.N.M. [printed] [yellow label] USNM ENT 00534203 [barcode] [printed] \\DO NOT REMOVE SI DB Reference Not a property tag T. Schultz NMNH [printed].

\section{Type locality}

Venezuela: Bolívar State: Rio Mato (“Caura district, Rio Mato").
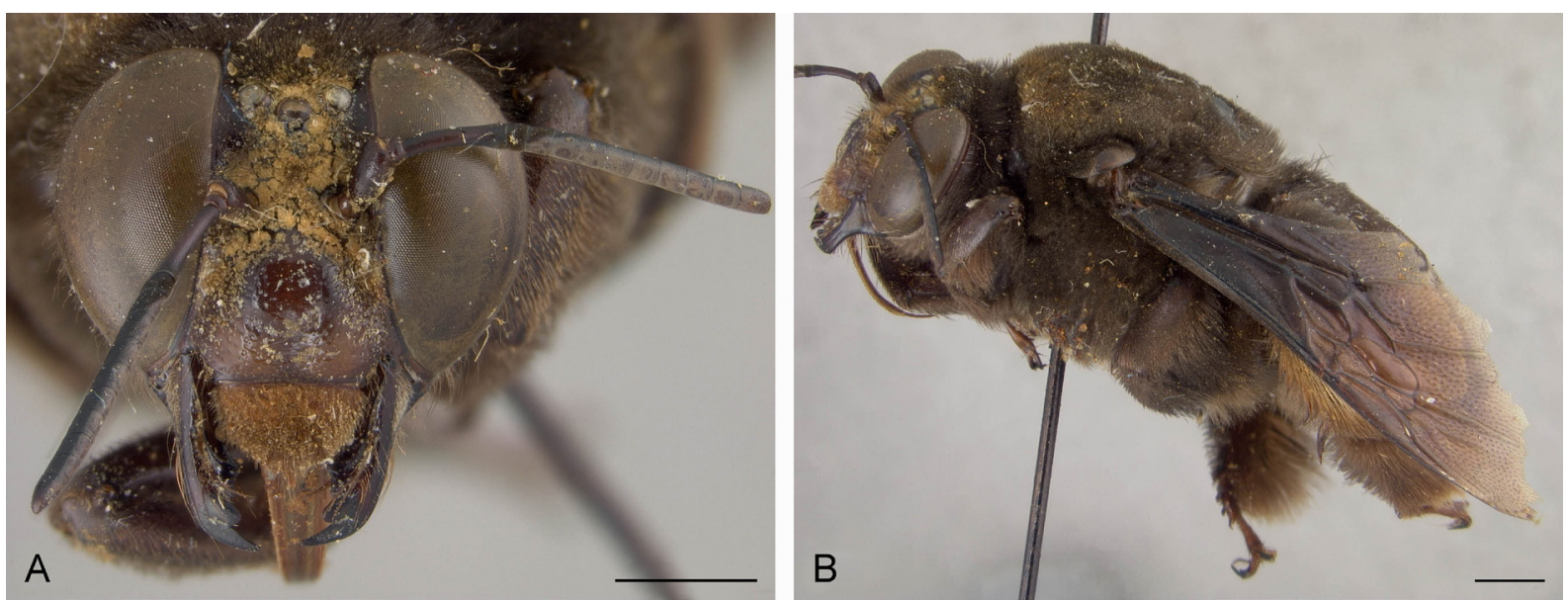

Fig. 19. Centris fusciventris matoensis Cockerell, 1919, holotype, $ð$ (NMNH; USNM ENT 00534203). A. Frontal view. B. Habitus, lateral view. Scale bars: $A=1 \mathrm{~mm} ; \mathrm{B}=2 \mathrm{~mm}$. 


\section{Comment}

Cockerell (1919) cited a specimen also collected by M. Carriker at the type locality of C. fusciventris caurensis and $C$. fusciventris matoensis as a subvariety of the latter subspecies. The characters cited by him about the integument of the clypeus and the pubescence on the fourth tergum are within the variation range of $C$. caurensis.

Centris maroniana Cockerell, 1917

Centris (Melanocentris) maroniana Cockerell, 1917: 475.

\section{Type data}

This species was described based on a single male specimen collected in Maroni, French Guiana. According to the original description, the specimen belonged to the Queensland Museum and was sent to Cockerell by Le Moult. Eugène LeMoult (1882-1967) was a French naturalist and entomologist specialist on butterflies who lived in French Guiana (Lhoste 1987). The holotype is housed at AMNH and

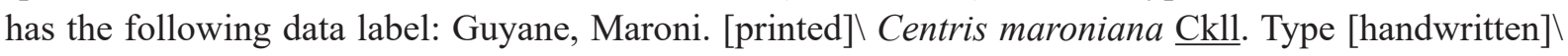
ac33337 [handwritten] $\backslash$ AMNH_IZC 00323439 [data matrix code] [printed].

\section{Type locality}

French Guiana: Maroni ("Guyane, Maroni”). It is not clear whether the type specimen was collected in Saint-Laurent-du-Maroni, one of the two sub-prefectures of French Guiana or near the Maroni River, a natural border between French Guiana and Suriname.

\section{Comment}

This is one of the most stunning species of the subgenus $C$. (Melanocentris). Unfortunately, nothing is known about its bionomy and distributional range.

Centris zamoranensis (Cockerell, 1949)

Fig. 20

Epicharis zamoranensis Cockerell, 1949: 480.

Junior synonym of C. (Melanocentris) melanochlaena Smith, 1874 (Moure et al. 2007).

\section{Type data}

This species was described based on a pair of at least two females collected by Geraldo Cisneros on November 3 and 5 at Zamorano, Honduras. The female collected on November 3 was found at NMNH and has the number 58888 in the catalog of types. According to the original description and the label that the found specimen bears, it was designated by Cockerell as the holotype. The specimen (Fig. 20) has the following data label: Zamorano. Honduras Nov. 3. (Cisneros) [handwritten] 17 [handwritten] Epicharis zamoranensis Ckll Type. [handwritten] [red label] Type No [printed] 58888 [handwritten] USNM [printed] \Centris (Melanocentris)! [handwritten] [yellow label] USNM ENT 00534219 [barcode] [printed] $\backslash$ DO NOT REMOVE SI DB Reference Not a property tag T. Schultz NMNH [printed]. The current condition and depository of the paratype(s) are unknown.

\section{Type locality}

Honduras: Francisco Morazán Department: Zamorano. 

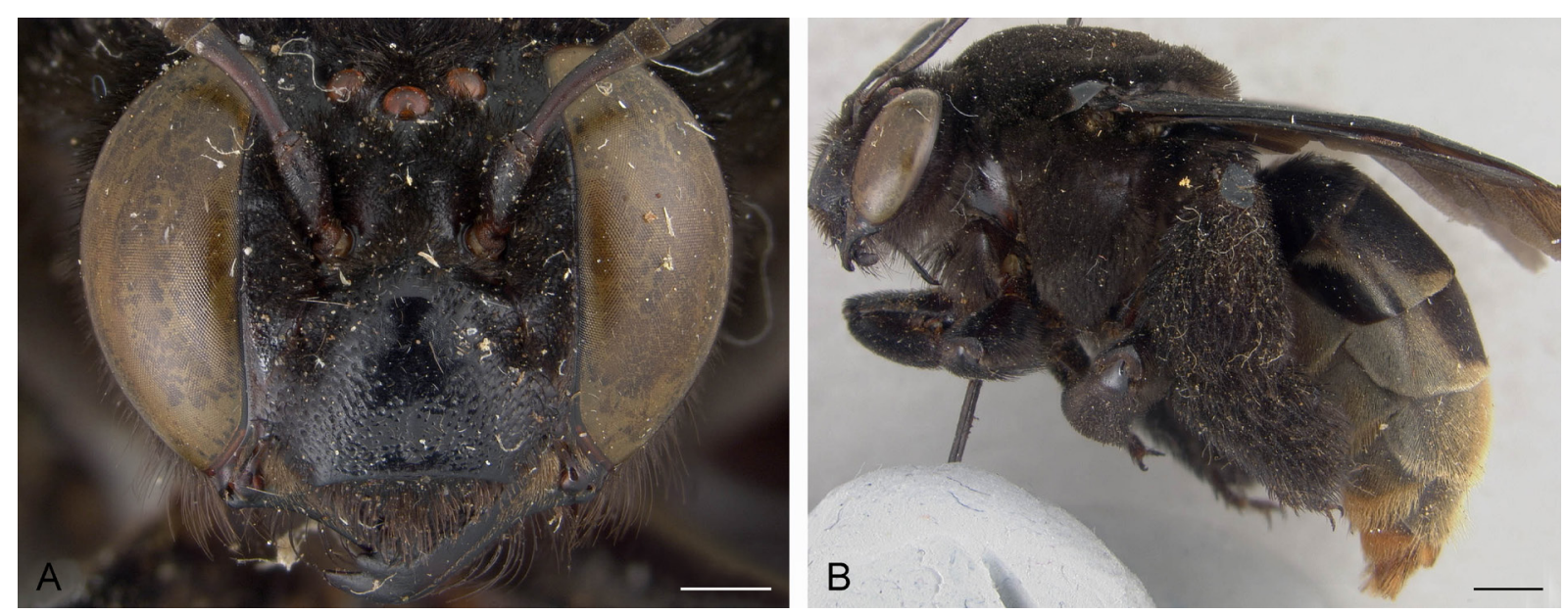

Fig. 20. Epicharis zamoranensis Cockerell, 1949, holotype, ㅇ (NMNH; USNM ENT 00534219). A. Frontal view. B. Habitus, lateral view. Scale bars: $A=1 \mathrm{~mm} ; \mathrm{B}=2 \mathrm{~mm}$.

\section{Comment}

Snelling (1984) proposed the synonymy of C. obsoleta Lepeletier, 1841, C. melanochlaena and C. zamoranensis, following the interpretation of Friese (1901) of the former species. Centris melanochlaena and C. zamoranensis are actually conspecific, but $C$. obsoleta is a different species restricted to South America. The synonymy proposed by Snelling (1984) was corrected by Moure et al. (2007), maintaining C. obsoleta and C. melanochlaena as different species, with $C$. zamoranensis as a junior synonym of the latter.

\section{Centris rufosuffusa Cockerell, 1935}

Centris rufosuffusa Cockerell, 1935b: 12-13.

\section{Type data}

Although the original description does not mention the number of males that were studied by Cockerell (1935b) to describe this species, the collector's note mentioned by him refers to an aggregation of males in a nesting area, which leads to believe that he could have used more than one specimen. However, one specimen studied by Cockerell (1935b) is currently housed at NHMUK bearing a label that agrees with the information cited in the original description. Considering this, I interpret that specimen as the holotype. It has the following data label: [circular label with red-rimmed margin] Type [printed] $\backslash$ Trinidad [printed] 2569 XI 33 [handwritten] FitzGerald [printed] $\backslash$ Centris rufosuffusa Ckll Type [handwritten] B.M. TYPE HYM. [printed] $17 b 1168$ [handwritten] $\backslash$ T.D.A.Cockerell B.M. 1934-527. [printed].

This specimen was collected in Point Radix, southeast coast of Trinidad Island, Trinidad and Tobago, by the Irish entomologist, ornithologist, conservationist and plant collector Leslie Desmond Edward Foster Vesey-Fitzgerald (1910-1974). Between 1933 and 1936, he conducted research work on the biological control of insect pests on sugar cane in Brazil, British Guiana and the British West Indies (Anonymous 1975). During this period, he collected the specimen(s) used by Cockerell (1935b) to describe this species.

\section{Type locality}

Trinidad and Tobago: Trinidad Island: Mayo-Rio Claro region: Point Radix.

\section{Comment}

This species was correctly interpreted by Moure et al. (2007). 
Subgenus Centris (Paracentris) Cameron, 1903

Centris caesalpiniae Cockerell, 1897

Centris caesalpiniae Cockerell, 1897a: 394-395.

\section{Type data}

This species was described based on one male and three females from Las Cruces, New Mexico, United States. According to the original description, Cockerell collected the type series on May 18, 1897, on Caesalpinia falcaria Fischer (Caesalpiniaceae). Two females were found at ZMB and ANSP bearing an original label of Cockerell that agrees with the data and the flower record cited by Cockerell. A female labeled "cotype" and a male labeled "Type" by Cockerell were found at NMNH and AMNH, respectively, but they don't have the date of collecting or the floral host. All these four specimens must compose the original type series studied by Cockerell. Although Cockerell (1897a) did not mention in the original description which specimen is the holotype, it can be inferred from the label of the male housed at AMNH. This interpretation is supported by the Articles 73.1.2 and 72.4.1.1 of the International Code of Zoological Nomenclature (ICZN 1999). The male holotype is haused at AMNH and has the following data label: Las Cruces NM [printed] $\backslash$ C. caesalpiniae Type $\lesssim$ [handwritten] $\backslash$ AMNH_IZC 00323433 [data matrix code] [printed]. Female paratype haused at ZMB has the following data label: Las Cruces NM [printed] $\backslash$ on Caesalpinia falcaria May 18. (Ck11) [handwritten] $\backslash$ caesalpiniae cotype [handwritten] $\backslash$ Centris caesalpiniae $\bigcirc$ Cockll [handwritten] 1910 Friese det. [printed] [orange label] Typus [printed] $\backslash$ Coll. Friese [printed]. Female paratype haused at ANSP has the following data label: Las Cruces NM [printed] \on Caesalpinia falcaria May 18. (Ck1l) [handwritten] C. caesalpiniae $ᄋ$ cotype. [handwritten] [red label] Type [printed] 1980 Loan to USNM from Acad. of Nat. Sciences at Philadelphia [printed]. Female paratype haused at NMNH has the following data label: Las Cruces NM [printed] $\backslash$ C. caesalpiniae $O$ cotype. [handwritten] $\backslash$ [red label] Co- [handwritten] Type No. [printed] 3149 [handwritten] U.S.N.M. [printed].

\section{Type locality}

United States: New Mexico State: Las Cruces.

Centris cisnerosi (Cockerell, 1949) nom. rev.

Fig. 21

Epicharis cisnerosi Cockerell, 1949: 480.

\section{Type data}

This species was described based on a single female specimen collected by Geraldo Cisneros on November 2, at Zamorano, central Honduras, foraging on Crotalaria L. sp. (Fabaceae). The type specimen (Fig. 21) is currently housed at NMNH under the number 58889 and has the following data label: Zamorano Honduras at Crotalaria Nov. 2. (Cisneros) [handwritten] 81 [handwritten] Epicharis cisnerosi Ckll Type. [handwritten] $\backslash$ Centris cisnerosi (Ckll) [handwritten] Det. J. S. Moure 19 [printed] 57 [handwritten] [yellow label] USNM ENT 00534191 [barcode] [printed] \ DO NOT REMOVE SI DB Reference Not a property tag T. Schultz NMNH [printed].

\section{Type locality}

Honduras: Francisco Morazán Department: Zamorano. 

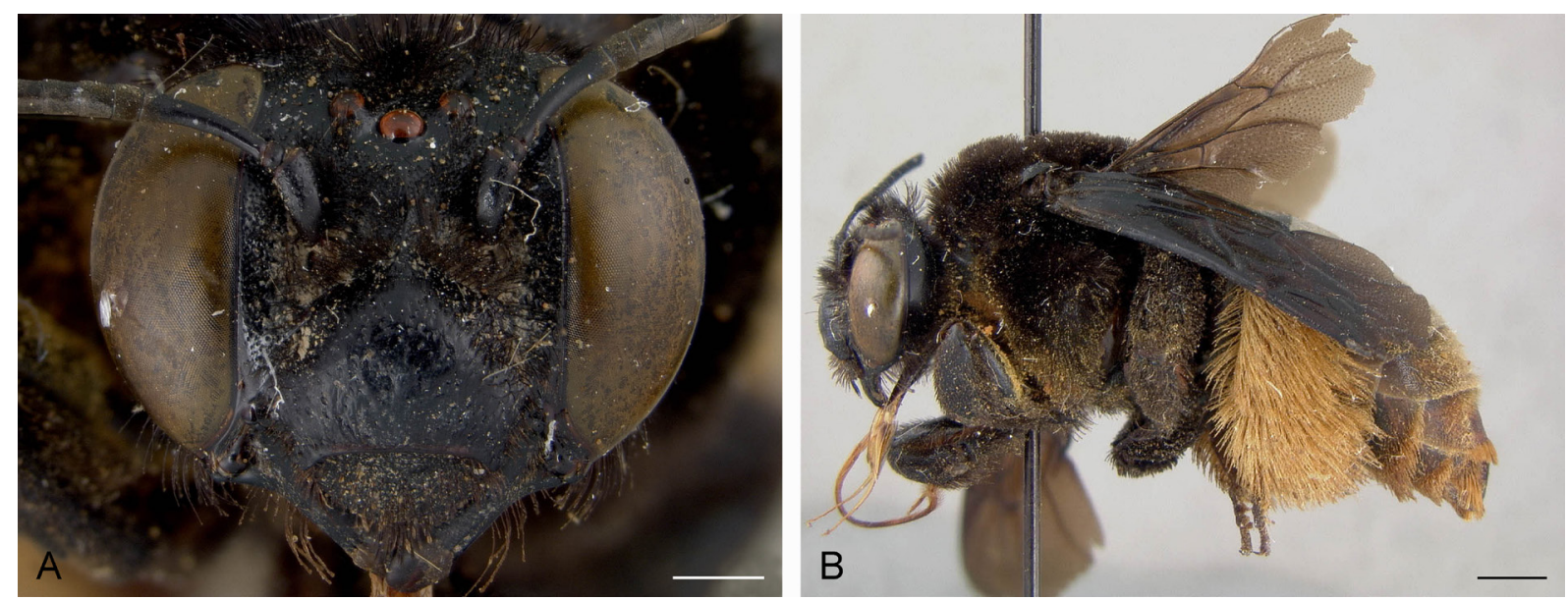

Fig. 21. Epicharis cisnerosi Cockerell, 1949, holotype, $q$ (NMNH; USNM ENT 00534191). A. Frontal view. B. Habitus, lateral view. Scale bars: $A=1 \mathrm{~mm} ; \mathrm{B}=2 \mathrm{~mm}$.

\section{Comments}

This species was proposed as a junior synonym of C. agilis Smith, 1874 by Snelling (1984), but it is actually a different, albeit similar species. Centris cisnerosi has terga 3 and 4 brown (reddish brown in C. agilis), terga 2 to 4 covered with a light yellow pubescence (brownish in C. agilis), and the lower half of the clypeus areolate laterally (not areolate in C. agilis). According to the morphology of the mandible and the basitibial and pygidial plates, $C$. cisnerosi and $C$. agilis are related to one of the internal linages of the subgenus $C$. (Paracentris), not to $C$. (Aphemisia) as mentioned by Moure et al. (2007). No information about the person that caught the type specimen was found, but probably he was a collector who helped Cockerell during his stay in Honduras (Jesus Orozco, pers. comm.).

Centris cockerelli resoluta Cockerell, 1923

Centris cockerelli resoluta Cockerell, 1923: 76-77.

Junior synonym of C. (Paracentris) cockerelli Fox, 1899 (Snelling 1984).

\section{Type data}

This subspecies was described based on male and female specimens collected by the American entomologist Edward Payson Van Duzee at La Paz, Lower California, on June 3, 1921. Cockerell (1923) designated the female as the holotype which is currently housed at CAS and has the following data label: La Paz Baja Calif. June 31921 [printed] $\backslash$ EPVanDuzee Collector [printed] \Centris cockerelli resoluta

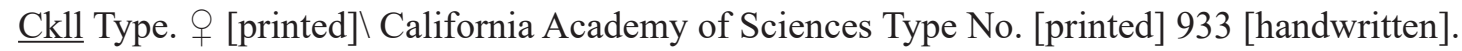

\section{Type locality}

Mexico: Baja California Sur State: La Paz.

Centris euphenax Cockerell, 1913

Centris euphenax Cockerell, 1913: 109-110.

\section{Type data}

This species was described based on a single male specimen collected by the American entomologist and dipterologist Charles Henry Typer Townsend (1863-1944) on March 27 during a trip to Peru. Townsend 
went there not to study bees, but cotton pests (Evenhuis 2013). He was a difficult man to work with and this no doubt led to his virtually isolating himself from other colleagues. Nevertheless, he and Cockerell had a cordial relationship and that could have facilitated the sending of some bees to be studied by this latter researcher. The male holotype, not female as mentioned in the original description, is housed at AMNH and has the following data label: Pachacayo. Peru. March. 27 [?] $12000 \mathrm{ft}$ [?] CHT Townsend. [handwritten]\Centris euphenax Ckll Type. [handwritten] ac33337 [handwritten].

\section{Type locality}

Peru: Junín Department: Pachacayo (“over 12,000ft.”).

\section{Comment}

This species was correctly interpreted by Moure et al. (2007).

Centris ferrisi Cockerell, 1924

Centris atripes ferrisi Cockerell, 1924: 49.

\section{Type data}

This species was described based on two male specimens collected by Gordon Floyd Ferris on June 29, 1919, at La Paz, Mexico. Ferris (1893-1958) was an American entomologist specialist on 'small insects', like lice, parasitic flies and small blood-sucking Hemiptera (Usinger 1959). In 1919, he made an extensive field trip to Baja California with the American herpetologist Joseph Richard Slevin (1881-1957), where both males studied by Cockerell (1924) were collected. In the original description, Cockerell (1924) did not indicate which male was the holotype, and he also failed to indicate the sex of the exemplars, citing that they were two females. Snelling (1984) recognized the latter mistake and corrected the sex of the specimens. According to Cockerell (1924), Snelling (1984) and Moure et al. (2007), the type specimens are housed at CAS, but actually they are in the NMNH. One of the males bears a label of "type" and the other was labeled as "cotype". The holotype has the following data label: [grey label] La Paz, Baja Calif., Mex. June 29, 1919 G. F. Ferris. [printed] $\backslash$ Centris atripes ferrisi Ckll Type [handwritten] $\backslash$ California Academy of Sciences Type No. [printed] 2729 [handwritten]. The male paratype has the following data label: [grey label] La Paz, Baja Calif., Mex. June 29, 1919 G. F. Ferris. [printed] $\backslash$ Centris atripes ferrisi Ckll Cotype [handwritten] \[red label] Paratype [printed] 54875 [handwritten] USNM [printed] $\backslash C$. (Penthemisia) ferrisi Ck1l [handwritten] Det. J.S.Moure 19 [printed] 57 [handwritten] $\backslash$ for me a good species Moure 57.

\section{Type locality}

Mexico: Baja California Sur State: La Paz.

\section{Comments}

According to Moure et al. (2007), this species occurs only in the Mexican States of Baja California and Baja California Sur.

\section{Centris hoffmanseggiae Cockerell, 1897}

Fig. 22

Centris hoffmanseggiae Cockerell, 1897a: 395-397.

\section{Type data}

On May 18, 1896, at Mesilla Valley, Cockerell collected, on flowers of Caesalpinia falcaria, one male and seven females that were used to describe this species. The male of the type series is currently 
housed at NMNH and was designated by Fox (1899) as the lectotype. The specimen (Fig. 22) has the following data label: Las Cruces Nm [printed] $\backslash$ on Caesalpinia falcaria. May 18. (Ck11) [handwritten] C. hoffmanseggiae Type. $\widehat{O}$ [handwritten] [red label] Type No [printed] 3148 [handwritten] USNM [printed] \[yellow label] USNM ENT 00534200 [barcode] [printed] \ DO NOT REMOVE SI DB Reference Not a property tag T. Schultz NMNH [printed]. The females cited by Cockerell were not found during this research.

\section{Type locality}

United States: New Mexico State: Las Cruces. Cockerell (1897a) mentioned that the type series was collected at "College Farm" in Mesilla Valley. Contrary to this information, the male studied by him bears a label of provenance of Las Cruces.
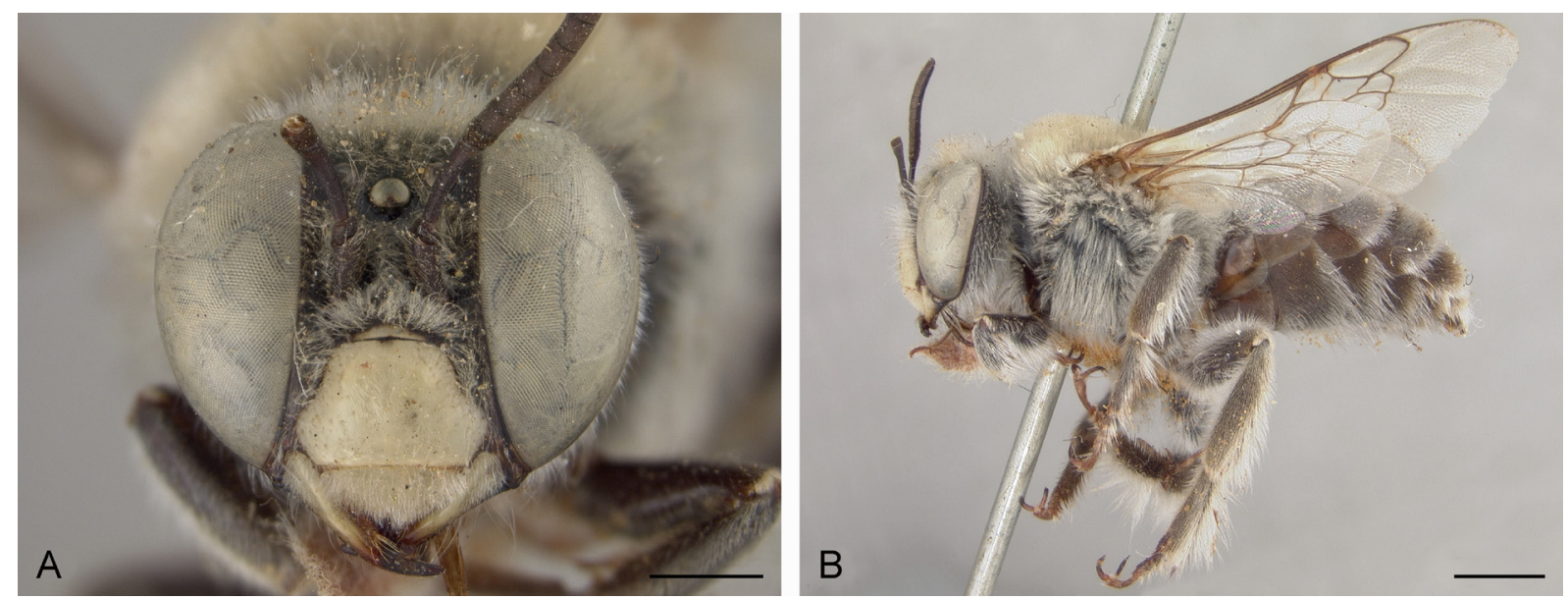

Fig. 22. Centris hoffmanseggiae Cockerell, 1897, lectotype, § (NMNH; USNM ENT 00534200). A. Frontal view. B. Habitus, lateral view. Scale bars: A $=1 \mathrm{~mm}$; $=2 \mathrm{~mm}$.

\section{Centris hoffmanseggiae davidsoni Cockerell, 1904}

Centris hoffmanseggiae subsp. davidsoni Cockerell, 1904a: 160.

Junior synonym of C. (Paracentris) hoffmanseggiae (Snelling 1956).

\section{Type data}

This subspecies was described based on a single male specimen collected by dr. Davidson, probably the British geodesist, astronomer and geographer George Davidson (1825-1911), who worked in California State since 1850 (Davenport 1937). The holotype is housed at CAS and has the following data label: Banning [handwritten] $\backslash$ Centris hoffmanseggiae davidsoni Ckll. Type. [handwritten] [red label] Holotype [printed] $\backslash$ California Academy of Sciences Type No. [printed] 15474 [handwritten].

\section{Type locality}

United States: California State: Banning.

\section{Centris morsei Cockerell, 1897}

Fig. 23

Centris morsei Cockerell, 1897b: 355.

Junior synonym of C. (Paracentris) caesalpiniae (Snelling 1974). 


\section{Type data}

This species was described based on a single metander male collected by the American entomologist specialist in Orthoptera Latreille, 1793 Albert Pitts Morse (1863-1936) at Mesilla, New Mexico State on June 28, 1897. The holotype (Fig. 23) is housed at NMNH and has the following data label: Mesilla. N.M. June 28. A.P. Morse. [handwritten] C. morsei, Ckll Type. [handwritten] [red label] Type No. [printed] 5096 [handwritten] U.S.N.M. [printed] \yellow label] USNM ENT 00534205 [barcode] [printed] $\backslash \backslash$ DO NOT REMOVE SI DB Reference Not a property tag T. Schultz NMNH [printed].

\section{Type locality}

United States: New Mexico State: Mesilla ("bed of the Rio Grande").
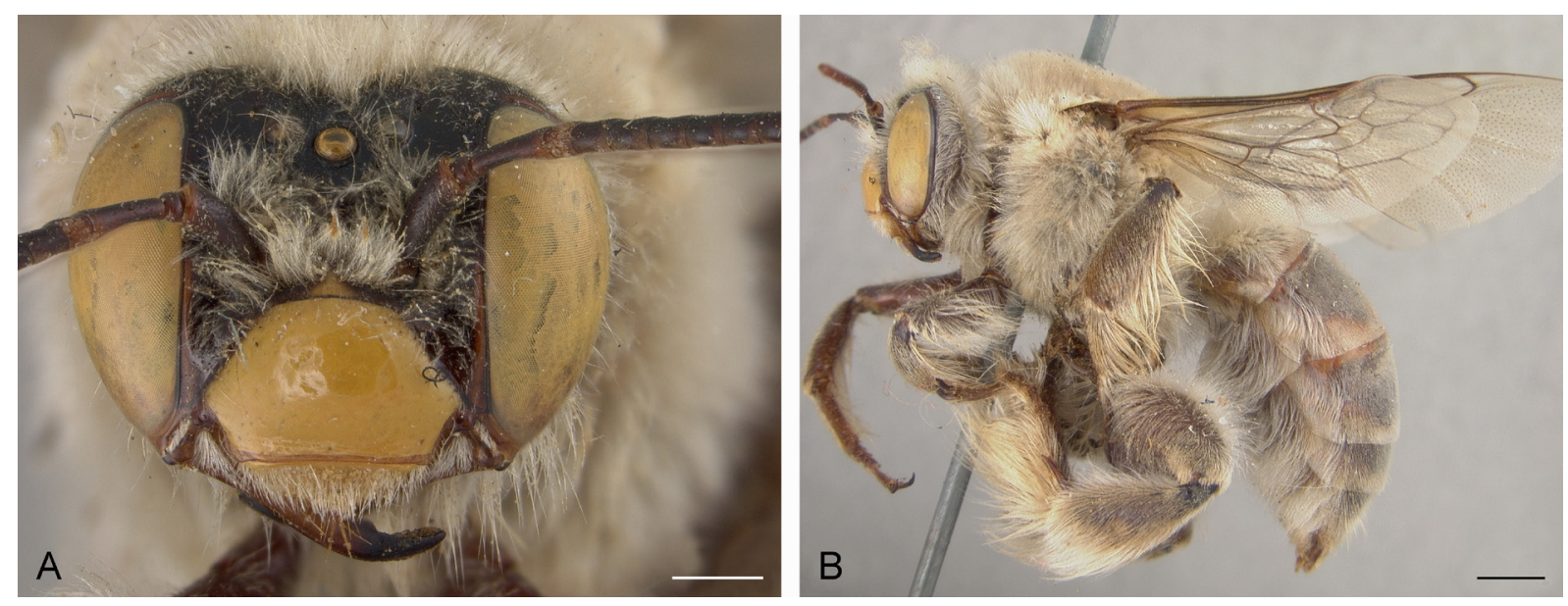

Fig. 23. Centris morsei Cockerell, 1897, holotype, §ิ (NMNH; USNM ENT 00534205). A. Frontal view. B. Habitus, lateral view. Scale bars: $A=1 \mathrm{~mm} ; B=2 \mathrm{~mm}$.

\section{Comments}

In the description of C. caesalpiniae, Cockerell (1897a) also mentioned a female collected by S. Steel on May 17, but it is not clear whether it belonged to the type series of the species. However, that specimen was not found in the collections visited during this research.

Moure et al. (2007) mentioned the existence of a type series of $C$. morsei, but this cannot be inferred from the original description or from the label of the specimen housed at NMNH. In this collection, another male was found with the following data label: [red label] $\widehat{\partial}$ [handwritten] Type No [printed] 5096 [handwritten] U.S.N.M. [printed] $\backslash$ C. morsei Mesilla. June 30. at fls. of Helianthus ciliaris A. P. Morsei [handwritten]. Although this specimen bears a red label of type, it is not part of the type series because the date of collecting is different from that cited in the original description, and it also has a flower record not mentioned by Cockerell (1897b).

Centris pallida callognatha Cockerell, 1923

Centris pallida callognatha Cockerell, 1923: 78.

Junior synonym of C. (Paracentris) pallida Fox, 1899 (Snelling 1956). 


\section{Type data}

This subspecies was described based on a single female specimen collected by Edward P. Van Duzee on April 11, 1921, at Guaymas, northwestern Mexico. The holotype is housed at CAS and has the following data label: Guaymas Mex. April 111921 [printed] $]$ EPVanDuzee Collector [printed] Centris pallida callognatha Ckll Type [handwritten] \California Academy of Sciences Type No. [printed] 934 [handwritten].

\section{Type locality}

Mexico: Sonora State: Guaymas.

Centris rhodoleuca Cockerell, 1923

Centris rhodoleuca Cockerell, 1923: 76.

Junior synonym of C. (Paracentris) rhodopus (Snelling 1974).

\section{Type data}

This species was described based on a single male specimen collected by E.P. Van Duzee at Punta Willard, Isla Tiburón, on July 3, 1921. The holotype is housed at CAS and has the following data label: Tiburon Isd Gulf Calif. July 31921 [printed] \Willard's Point Bay [printed] $\backslash$ EPVanDuzee Collector [printed] $\backslash$ Centris rhodoleuca Ckll. Type. [handwritten] $\backslash$ California Academy of Sciences Type No. [printed] 932 [handwritten].

\section{Type locality}

Mexico: Sonora State: Isla Tiburón: Punta Willard.

\section{Comment}

The type specimen of Centris rhodoleuca looks very different from males of C. rhodopus, but it is actually conspecific, corresponding to a metander male.

Centris rhodopus Cockerell, 1897

Centris caesalpiniae var. rhodopus Cockerell, 1897a: 395.

\section{Type data}

This species was described based on two males and two females collected by Cockerell in Mesilla Valley, United States, foraging on Caesalpinia falcaria. One of those females was found at ANSP and one male at NMNH. Both specimens bear a label "cotype" and are in good condition. According to the treatment that Cockerell gave to his type specimens, both these exemplars must be paratypes. The male has the following data label: Las Cruces Nm [printed] $\backslash$ on Caesalpinia stricta May 18. (Ck11) [handwritten] $\backslash$ C. rhodopus cotype. $\widehat{\jmath}$. [handwritten] $\backslash$ California Academy of Sciences Type No. [printed] 15473 [handwritten]. The female paratype has the following data label: Las Cruces Nm [printed] $\backslash$ on Caesalpinia stricta May 18. (Ck1l) [handwritten] $\backslash$ C. rhodopus cotype. + [handwritten] [red label] type [printed] $\backslash 1980$ Loan to USNM from Acad. of Nat. Science at Philadelphia [printed]. The current condition and depository of the holotype are unknown.

\section{Type locality}

United States: New Mexico State: Mesilla Valley (“College Farm”). 
Centris rhodopus pulchrior Cockerell, 1900

Fig. 24

Centris rhodopus var. pulchrior Cockerell, 1900: 363.

Junior synonym of C. (Paracentris) rhodopus (Snelling 1974).

\section{Type data}

This species was described based on a single male specimen collected at Mesilla Park, New Mexico, on June 24. The holotype (Fig. 24) is housed at NMNH and has the following data label: Mesilla Park. June 24. (Ck1l) [handwritten] $\backslash$ C. rhodopus v. pulchrior Ckll Type. [handwritten] [red label] Type No [printed] 5802 [handwritten] U.S.N.M. [printed] [yellow label] USNM ENT 00534208 [barcode] [printed] $\backslash \backslash$ DO NOT REMOVE SI DB Reference Not a property tag T. Schultz NMNH [printed].

\section{Type locality}

United States: New Mexico State: Mesilla Park.

\section{Comment}

Centris rhodopus pulchrior is slightly larger than normal males of C. rhodopus, the hairs on the hind legs are lighter and the whitish bands on the terga are more defined.
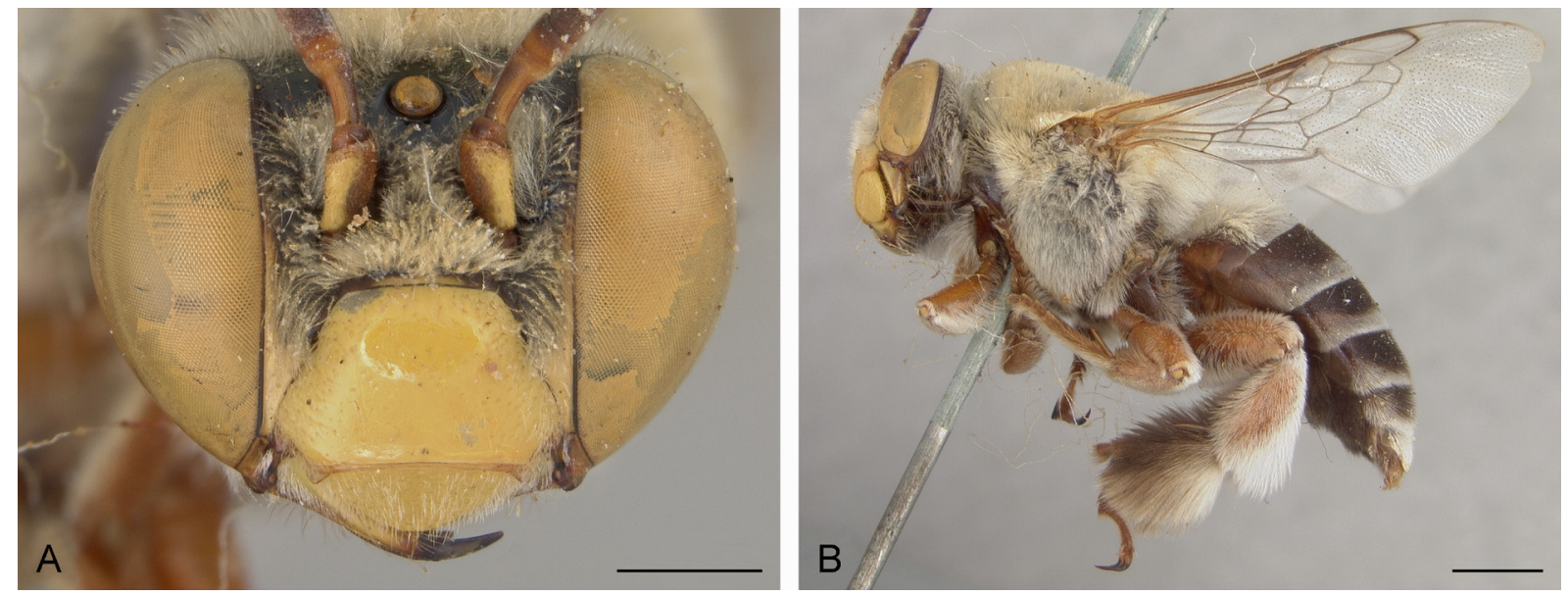

Fig. 24. Centris rhodopus pulchrior Cockerell, 1900, holotype, $\widehat{\jmath}$ (NMNH; USNM ENT 00534208). A. Frontal view. B. Habitus, lateral view. Scale bars: A = $1 \mathrm{~mm} ; \mathrm{B}=2 \mathrm{~mm}$.

Centris tiburonensis Cockerell, 1923

Centris tiburonensis Cockerell, 1923: 78.

\section{Type data}

This species was described based on a single female specimen collected by E.P. Van Duzee at Isla Tiburón, Mexico, on April 23, 1921. The holotype is housed at CAS and has the following data label: Tiburon Isd Gulf Calif. Apr. 231921 [printed] $\backslash$ Freshwater Bay [printed] $\backslash$ EPVanDuzee Collector [printed] $\backslash$ Centris tiburonensis Ckll. Type. [handwritten] $\backslash$ California Academy of Sciences Type No. [printed] 935 [handwritten]. 


\section{Type locality}

Mexico: Sonora State: Isla Tiburón: Freshwater Bay.

\section{Comment}

This species was correctly interpreted by Snelling (1966) and Moure et al. (2007).

Centris trichosoma Cockerell, 1923

Centris trichosoma Cockerell, 1923: 78-79.

Junior synonym of C. (Paracentris) pallida (Snelling 1956).

\section{Type data}

This species was described based on a male specimen collected by E.P. Van Duzee in Baja California, Mexico. The male paratype was collected at Freshwater Bay, Tiburon Island, on April 23, 1921. These specimens were not examined during this research.

\section{Type locality}

Mexico: Baja California State: Bahía de Los Ángeles.

Centris vanduzeei Cockerell, 1923

Centris vanduzeei Cockerell, 1923: 75-76.

\section{Type data}

This species was described based on male and female specimens collected by E.P. Van Duzee during an expedition to the Gulf of California, Mexico. The female holotype, currently housed at CAS, was collected at San José Island on May 28, 1921, and has the following data label: San Jose I. Gulf Calif. May 281921 [printed]\ EPVanDuzee Collector [printed]\Centris vanduzeei Ckll Type. [handwritten].

\section{Type locality}

Mexico: Baja California Sur State: Isla San José.

\section{Comment}

According to Moure et al. (2007), there is a female paratype housed at NMNH, but it was not found in that collection.

$$
\text { Subgenus Centris (Penthemisia) Moure, } 1950
$$

Centris bicolorella Cockerell, 1904

Centris bicolorella Cockerell, 1904b: 235 (nom. nov. for Centris smithii Friese, 1899).

Junior synonym of C. (Penthemisia) chilensis (Spinola, 1851) (Alfken 1904).

\section{Comment}

The synonymy between $C$. smithii and C. chilensis was proposed in 1904 by Alfken, the same year that Cockerell proposed the name C. bicolorella for the species described by Friese (1899). Apparently, Cockerell did not notice the synonymy because he did not have access to Alfken's article. This can be 
supposed because Alfken's article was published on June 30 while Cockerell's paper appeared in the issue released in September.

Centris wilmattae Cockerell, 1926

Centris (Trachina) wilmattae Cockerell, 1926a: 224.

Junior synonym of C. (Penthemisia) buchholzi Herbst, 1918 (Zanella 2002).

\section{Type data}

This species was described based on a single female specimen collected by Wilmatte P. Cockerell in southern Peru on August 22. The holotype is housed at AMNH and has the following data label: Tingo. Peru. Aug. 22. (W.P.Cockerell) [handwritten] Centris wilmattae Ckll. Type. [handwritten] ac33337 [handwritten] \entris buchholzi Herbst, 1918 F. Zanella det., 1999 [printed] $\backslash$ AMNH_IZC 00323441 [data matrix code] [printed].

\section{Type locality}

Peru: Arequipa Department: Tingo.

\section{Comment}

Centris buchholzi was described by Herbst (1918) based on male and female specimens collected in Tocopilla, northern Chile. Two males of the type series are housed at MCZ, one of them with the metasoma missing. The complete male is here designated the lectotype, and it has the following data label: Chile 190 P. Herbst [printed] Nord Chile Tocopilla 10.X.1916 [handwritten in red ink] Centris buchholzi $\widehat{\supset}$ P. Herbst in litt. Type [handwritten in red ink] $\backslash$ P. Herbst Collection [printed] [red label] M.C.Z. Type [printed] 23334 [handwritten] $\backslash$ MCZ-ENT 00023334 [QR code] [printed]. The male paralectotype has the following data label: Chile 190 P. Herbst [printed] Nord Tocopilla 10.X.1916 $[$ handwritten in red ink] Centris buchholzi $\widehat{\jmath}$ P. Herbst in litt. Type [handwritten in red ink] P. Herbst Collection [printed] [ [red label] M.C.Z. Type [printed] 23334 [handwritten] $\backslash$ MCZ-ENT 00511493 [QR code] [printed]. The current condition and depository of the female paralectotype are unknown. The fixation of the lectotype allows confirmation of the synonymy between this species and $C$. wilmattae proposed by Zanella (2002).

Subgenus Centris (Ptilocentris) Snelling, 1984

Centris chlorura Cockerell, 1919

Fig. 25

Centris chlorura Cockerell, 1919: 188-189.

\section{Type data}

This species was described based on a single female specimen collected in the central highlands of Peru. The holotype (Fig. 25) is housed at NMNH and has the following data label: Piches \& Perene Vs 2000-3000ftPeru SocGeogdeLima [printed] \Centris chlorura Ckll. Type. [handwritten] [red label] Type No. [printed] 21651 [handwritten] U.S.N.M. [printed] [yellow label] USNM ENT 00534190 [barcode] [printed] \ DO NOT REMOVE SI DB Reference Not a property tag T. Schultz NMNH [printed].

\section{Type locality}

Peru, Junín Department (“Piches and Perene Valleys, 2000-3000 feet”). 

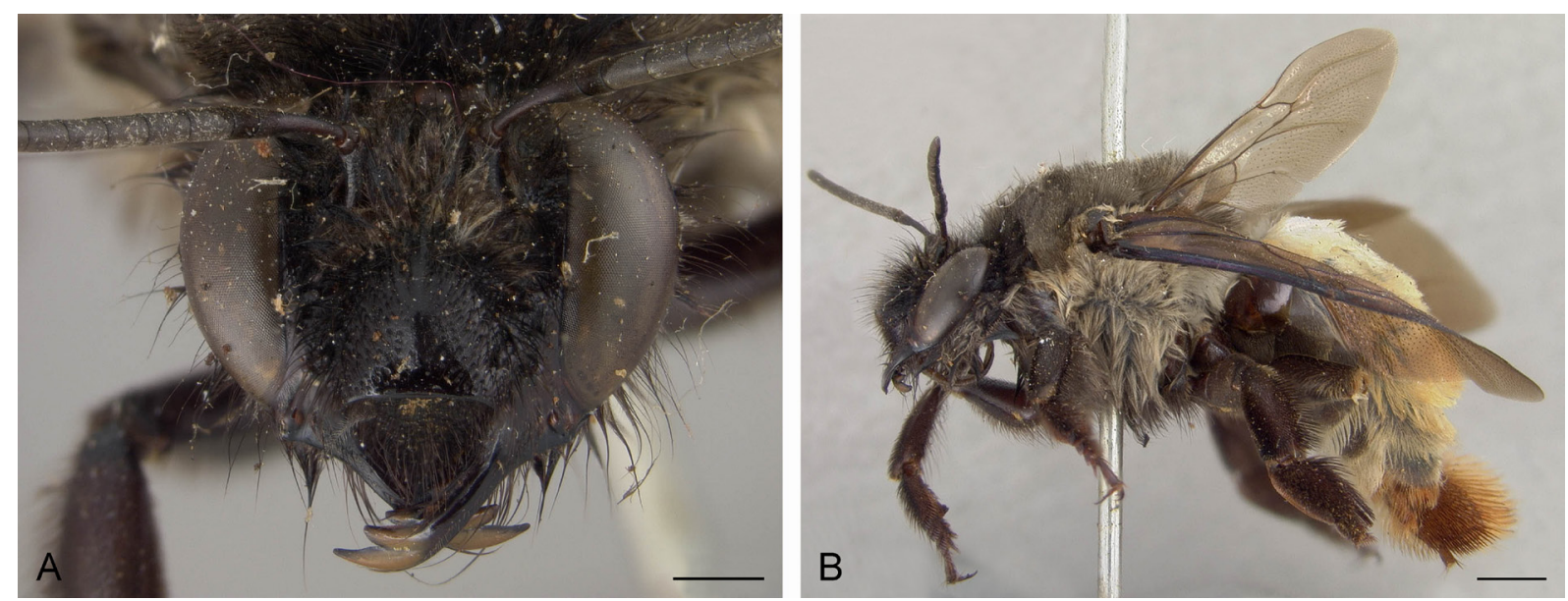

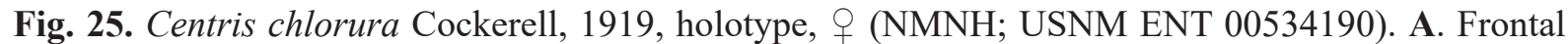
view. B. Habitus, lateral view. Scale bars: $A=1 \mathrm{~mm} ; B=2 \mathrm{~mm}$.

\section{Comment}

Centris chlorura has only been recorded from its type locality. Snelling (1984) erroneously proposed this species as a junior synonym of $C$. festiva Smith, 1854. This mistake was emended by Moure et al. (2007).

\section{Subgenus Centris (Trachina) Klug, 1807}

Centris bimaculata carrikeri Cockerell, 1919

Fig. 26

Centris bimaculata carrikeri Cockerell, 1919: 188.

New junior synonym of $C$. (Trachina) claripennis Friese, 1901.

\section{Type data}

It is not clear from the original description how many females were used by Cockerell (1919) to describe this subspecies. However, it was apparently based on a single specimen collected by Melbourne A. Carriker in Aroa city, northwestern Venezuela. The holotype (Fig. 26) is currently housed at NMNH and has the following data label: Aroa Venez [printed] $\backslash$ Dec. 16.10 [handwritten] $\backslash$ MACarriker collector [printed] $\backslash$ on Aster [handwritten] Centris bimaculata carrikeri Ckll. Type. [handwritten] [red label] Type No. [printed] 21150 [handwritten] U.S.N.M. [printed] [yellow label] USNM ENT 00534188 [barcode] [printed] $\backslash$ DO NOT REMOVE SI DB Reference Not a property tag T. Schultz NMNH [printed].

\section{Type locality}

Venezuela: Yaracuy State: Aroa.

\section{Comments}

Centris claripennis was erroneously described from São Paulo, southeastern Brazil. Its distribution range in South America includes Colombia, Venezuela, and Trinidad and Tobago (unpubl. data). This species was erroneously proposed as a junior synonym of C. fuscata Lepeletier, 1841 (Moure et al. 2007). The study of the type specimens of both species allows removing the former species from the synonymy of the latter, proposing its revalidation. Both sexes of $C$. claripennis can easily be identified by the yellowish coloration of the wings, being dark brown on the distal half. 

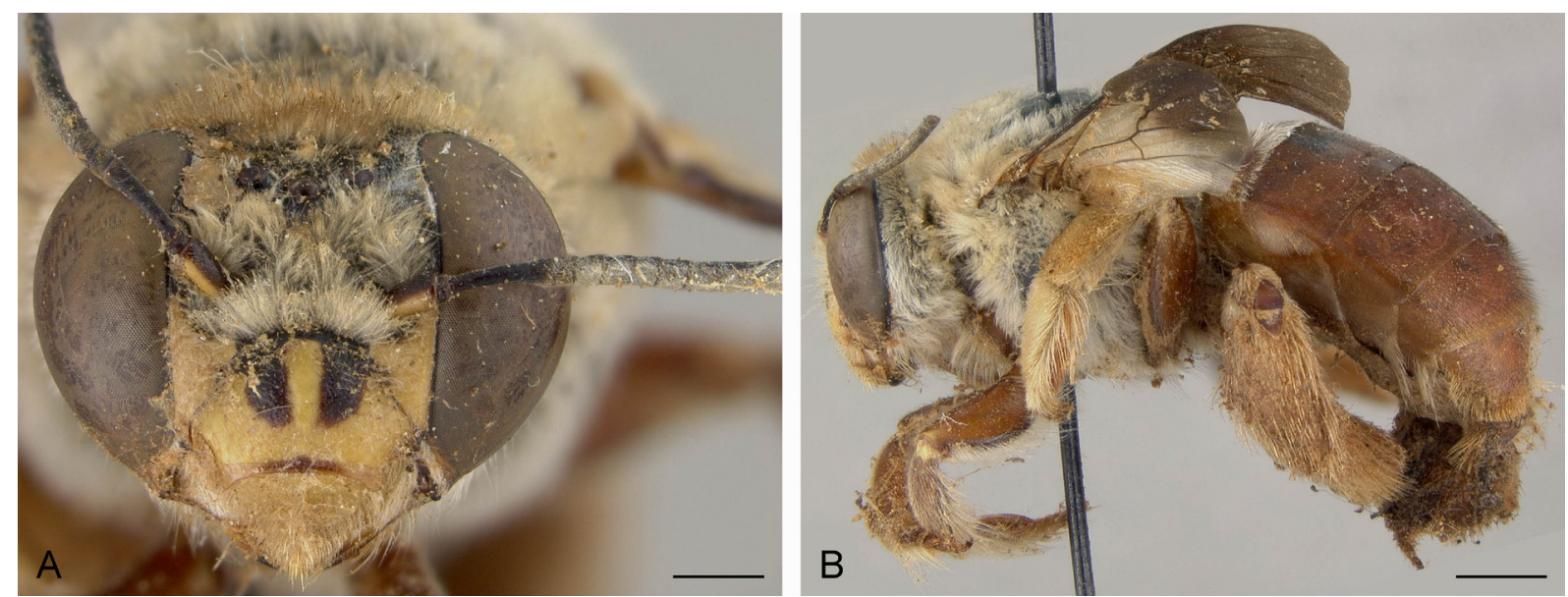

Fig. 26. Centris bimaculata carrikeri Cockerell, 1919, holotype, q (NMNH; USNM ENT 00534188). A. Frontal view. B. Habitus, lateral view. Scale bars: A = $1 \mathrm{~mm}$; $\mathrm{B}=2 \mathrm{~mm}$.

Centris heterodonta Cockerell, 1912

Centris (Ptilotopus) heterodonta Cockerell, 1912a: 43-44.

New junior synonym of $C$. (Trachina) dentata Smith, 1854.

\section{Type data}

As for Centris bakeri, the female specimen studied by Cockerell to describe this species was collected by William Mann and Fred Baker in Rio Madeira, Rondônia State, northern Brazil. The holotype is currently housed at AMNH and has the following data label: Porto Velho, Rio Madeirrazil Mann \&

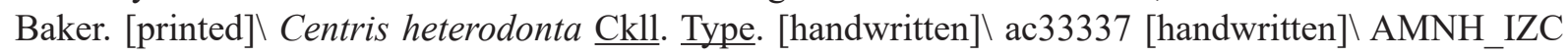
00323437 [data matrix] [printed].

\section{Type locality}

Brazil: Rondônia State: Rio Madeira.

\section{Comments}

The study of the type specimens of $C$. dentata and $C$. heterodonta allows proposing the synonymy between these both species. Despite the distribution range mentioned by Moure et al. (2007), this species occurs only in South America (unpubl. data).

\section{Centris pachysoma Cockerell, 1919}

Fig. 27

Centris pachysoma Cockerell, 1919: 189.

\section{Type data}

Cockerell (1919) described this species based on a single female specimen collected by William Rosenberg, the same collector of the type specimen of $C$. calloxantha (see below). The holotype (Fig. 27) is housed at NMNH and has the following data label: Palcazu Peru [printed] [?] Rosenberg

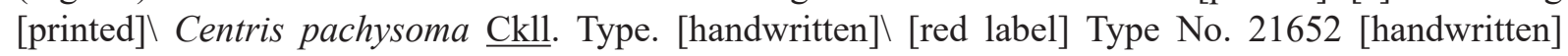
U.S.N.M. [printed] [yellow label] USNM ENT 00534206 [barcode] [printed] \ DO NOT REMOVE SI DB Reference Not a property tag T. Schultz NMNH [printed]. 

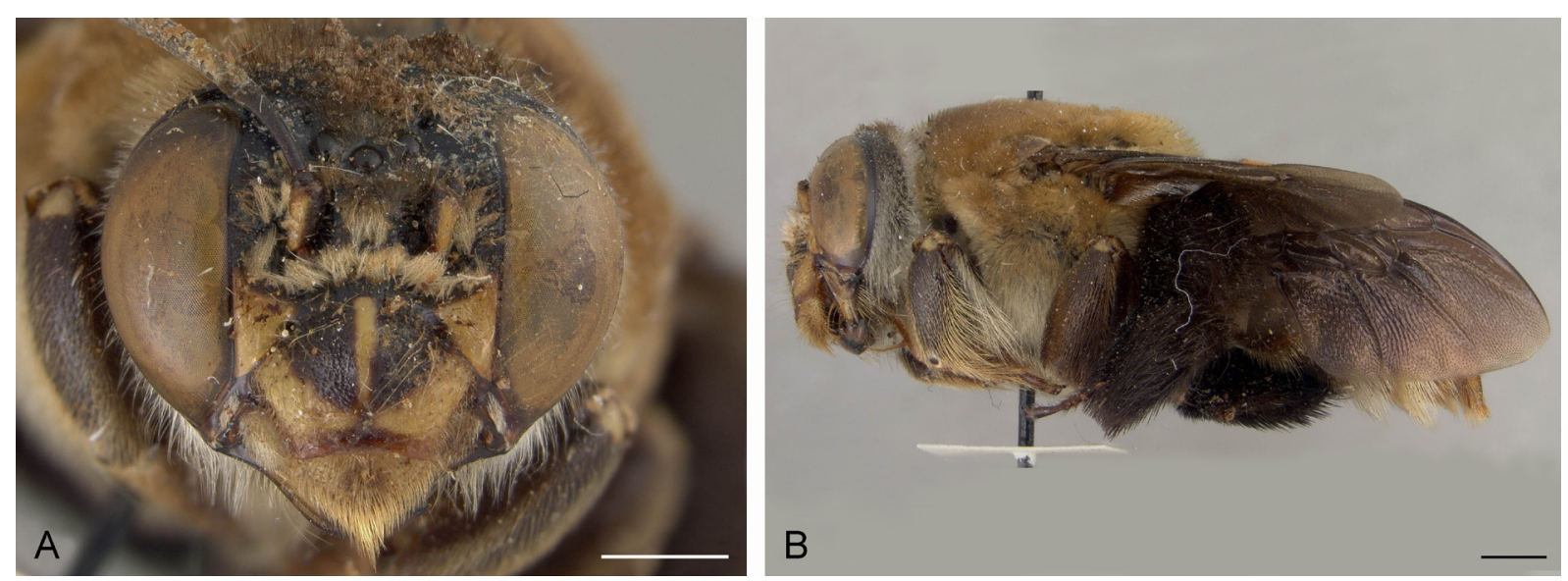

Fig. 27. Centris pachysoma Cockerell, 1919, holotype, $q$ (NMNH; USNM ENT 00534206). A. Frontal view. B. Habitus, lateral view. Scale bars: $A=1 \mathrm{~mm} ; B=2 \mathrm{~mm}$.

\section{Type locality}

Peru: Pasco Department: Palcazú.

\section{Comment}

This species was correctly interpreted by Moure et al. (2007).

Centris schwarzi Cockerell, 1919

Fig. 28

Centris schwarzi Cockerell, 1919: 192.

Junior synonym of C. (Trachina) labiata Friese, 1904 (Snelling 1984).

\section{Type data}

This species was described based on a single female specimen collected in Cacao, northern Guatemala, by two renowned entomologists, the German-American Eugene Amandus Schwarz (1844-1928) (Howard 1928) and the American Herbert Spencer Barber (1882-1950). Both researchers were skillful collectors specialized in the study of beetles (Caudell 1907). The holotype (Fig. 28) is currently housed at NMNH and has the following data label: Cacao [printed] 190426.3 [handwritten] Guat [printed] $\backslash$ Alta V. Paz Guatemala [printed] $\backslash$ Barber \& Schwarz Coll [printed]\Centris schwarzi Ckll. Type. [handwritten] [red label] Type No. [printed] 21657 [handwritten] U.S.N.M. [printed] [yellow label] USNM ENT 00534214 [barcode] [printed] $\backslash$ DO NOT REMOVE SI DB Reference Not a property tag T. Schultz NMNH [printed].

\section{Type locality}

Guatemala: Alta Verapaz Department: Cacao.

\section{Comment}

Taxonomic decision for synonymy: Snelling (1984). 

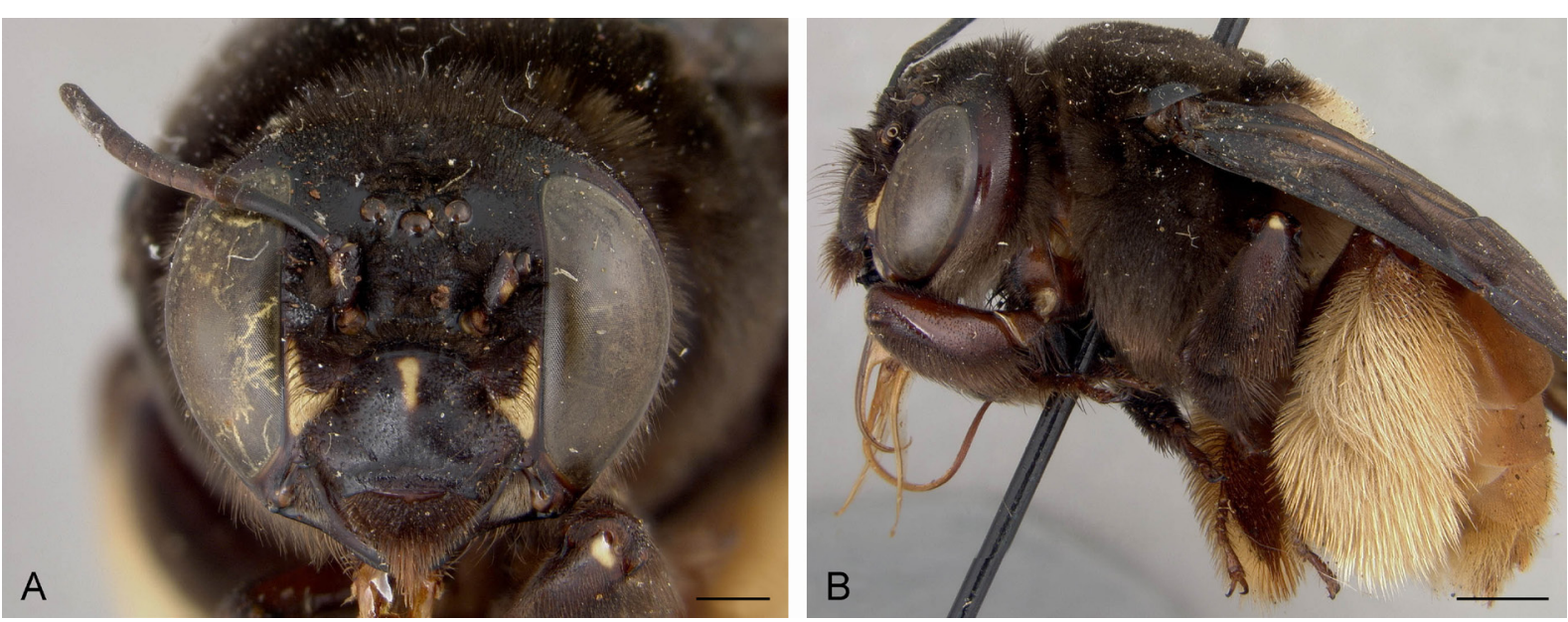

Fig. 28. Centris schwarzi Cockerell, 1919, holotype, + (NMNH; USNM ENT 00534214). A. Frontal view. B. Habitus, lateral view. Scale bars: $A=1 \mathrm{~mm} ; B=2 \mathrm{~mm}$.

\section{Subgenus Centris (Wagenknechtia) Moure, 1950}

Centris escomeli Cockerell, 1926

Fig. 29

Centris escomeli Cockerell, 1926b: 28-29.

\section{Type data}

This species was described based on a couple of female and male specimens collected in Arequipa, southern Peru. Both specimens were collected by Edmundo Escomel (1880-1959), a Peruvian doctor who dedicated his free time as a meticulous observer of the flora, fauna and the natural environment (Velarde 2006). The male holotype (Fig. 29) and the female paratype are housed at the NMNH. The holotype has the following data label: Arequipa Peru (Escomel) [handwritten] $\backslash$ Centris escomeli $\underline{\text { Ckll. }}$. Type [handwritten] [red label] Type No. [printed] 40493 [handwritten] U.S.N.M. [printed] $\backslash$ [yellow label] USNM ENT 00534193 [barcode] [printed] \ DO NOT REMOVE SI DB Reference Not a property
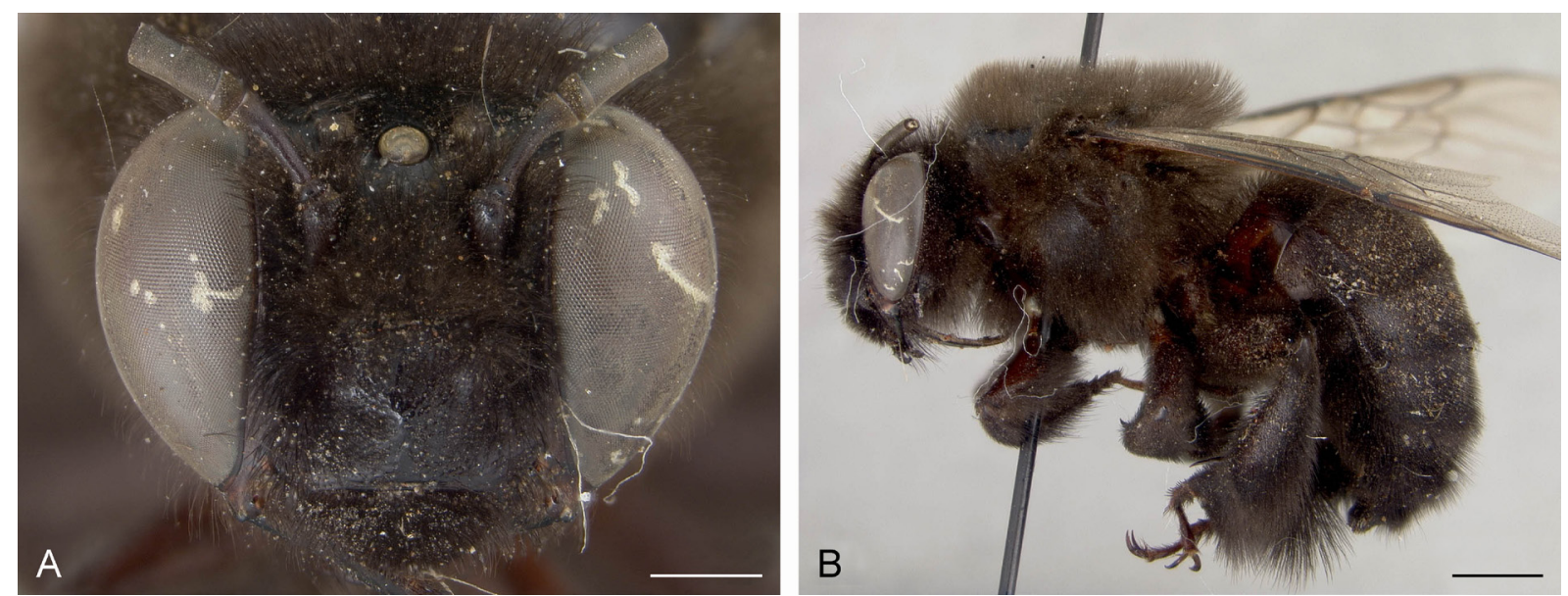

Fig. 29. Centris escomeli Cockerell, 1926, holotype, ô (NMNH; USNM ENT 00534193). A. Frontal view. B. Habitus, lateral view. Scale bars: $A=1 \mathrm{~mm} ; B=2 \mathrm{~mm}$. 
tag T. Schultz NMNH [printed]. The female paratype has the following data label: Arequipa Peru.

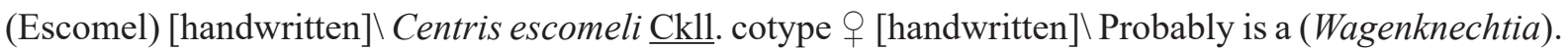

\section{Type locality}

Peru: Arequipa.

\section{Comment}

This species was correctly interpreted as a valid species by Moure et al. (2007) and Vivallo (2013).

\section{Subgenus Centris (Xanthemisia) Moure, 1945}

Centris calloxantha Cockerell, 1919

Fig. 30

Centris calloxantha Cockerell, 1919: 187.

Junior synonym of $C$. (Xanthemisia) bicolor Lepeletier, 1841 (Moure et al. 2007).

\section{Type data}

Cockerell (1919) did not specify how many males he studied to describe this species. According to the labels of the type specimen housed at NMNH, it was based on a single specimen collected by William Rosenberg in Chanchamayo, Peru. The holotype (Fig. 30) has the following data label: Chauchamayo Peru [printed] $\backslash$ From WFH Rosenberg [printed]\ Centris calloxantha Ckll. Type. [handwritten] [red label] Type No. [printed] 21649 [handwritten] U.S.N.M. [printed] [yellow label] USNM ENT 00534187 [barcode] [printed] $\backslash$ DO NOT REMOVE SI DB Reference Not a property tag T. Schultz NMNH [printed].

\section{Type locality}

Peru: Junín Department: Chanchamayo (“Chauchamayo").
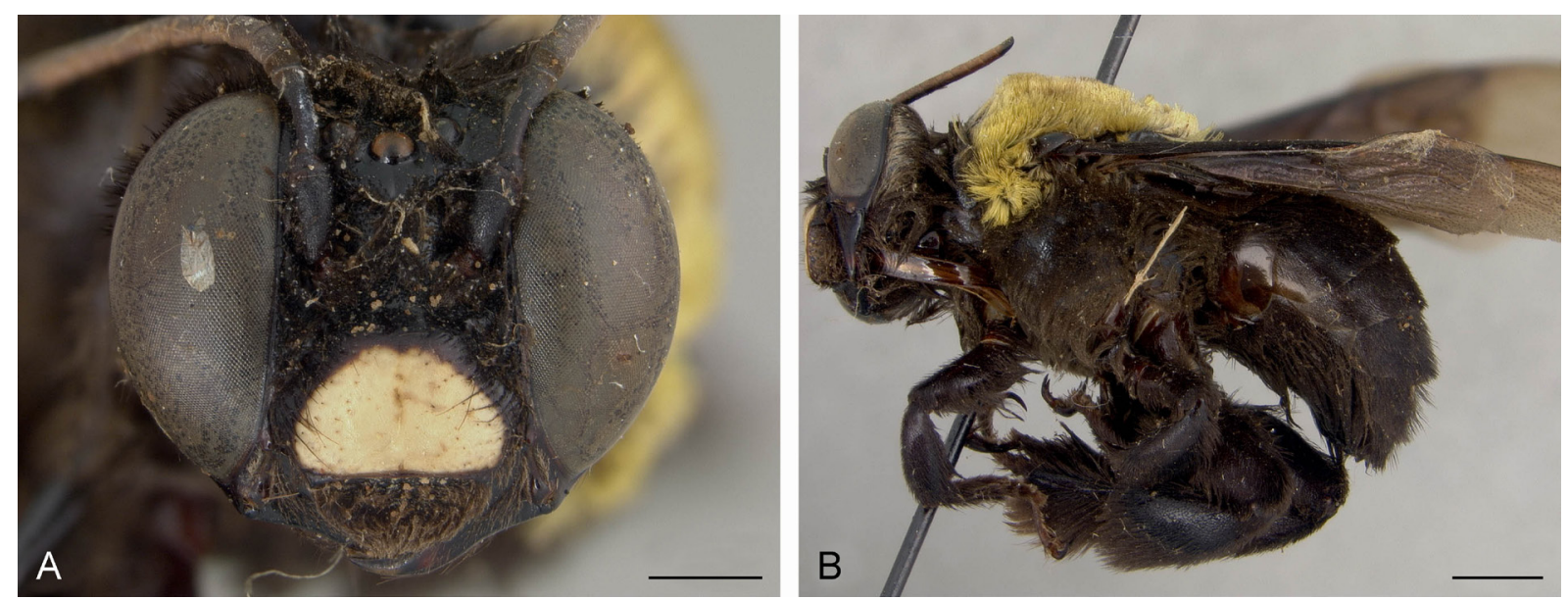

Fig. 30. Centris calloxantha Cockerell, 1919, holotype, § (NMNH; USNM ENT 00534187). A. Frontal view. B. Habitus, lateral view. Scale bars: $A=1 \mathrm{~mm} ; B=2 \mathrm{~mm}$. 


\section{Comment}

The species described by Cockerell only differs from normal males of C. bicolor by the presence of dark brown hairs on the mesoscutum.

Centris hyptidis group

Centris libertatis Cockerell, 1912

Centris (Ptilotopus) libertatis Cockerell, 1912a: 44-45.

Junior synonym of C. hyptidis Ducke, 1908 (Moure et al. 2007).

\section{Type data}

The type specimen of this species was collected in 1911 during the Stanford Expedition by the embryologist Harold Heath (1868-1951) and the student of zoology William Mann (1886-1960) (Oliveira 2014) at "Independencia", Paraíba State, northeastern Brazil. The type specimen is currently housed at AMNH and has the following data label: Independencia, Parahyba, Brazil Mann \& Heath. [printed] \Centris libertatis Ckll Type. [handwritten] ac33337 [handwritten] $\backslash$ AMNH_IZC 00323438 [data matrix code] [printed].

\section{Type locality}

Brazil: Paraíba State: Independência.

\section{Discussion}

As is generally the case with particularly diverse lineages, the taxonomy at specific level can be quite complex, not only because of the large number of species described, but also because of the large number of the synonymies proposed throughout the taxonomic history of the group. This is observed in Centris, where approximately one third of the proposed names are currently considered synonymous (see Moure et al. 2007).

The access to the type material, along with its careful study, allows evaluating the status of each proposed name, as well as, in some cases, to solve misidentifications or misinterpretations that originated in the past and have remained unnoticed until now (see, for example, Vivallo 2019, 2020). It is logical to think that in Centris, as well as in other especially diverse groups of bees, the real number of species will change in the future, once the primary types of all the proposed species are studied. This will allow not only to correct erroneous identifications of specimens deposited in collections and museums, but also to recognize and describe new species and, above all, to correctly associate the bionomic data and ecological relationships that are being continuously published, with the real identity of the species that are being studied.

The detailed record of the primary types, their labels and the confirmation of their repository are fundamental steps to solve current taxonomic problems and avoid future problems related to the identity of the species. This also allows other taxonomists to have appropriate tools to locate and recognize which specimens were specifically studied by the authors of each species at the time they described them, facilitating their re-study or reinterpretation if necessary.

\section{Acknowledgments}

I thank Jerome Rozen and Corey Smith (AMNH), Jason Weintraub (ANSP), Zoltán Vas (HNHM), Agnièle Touret-Alby (MNHN), Orlando Tobias Silveira (MPEG), David Notton (NHMUK), James 
Hogan (OUMNH), Seán Brady (NMNH), and Michael Ohl (ZMB) for allowing me to visit their institutions to study the specimens under their care. I also thank Robert Zuparko, Norman Penny, Vince Lee (CAS), Stefan Cover (MCZ), Lars Vilhelmsen (NHMD), Jesús Orozco (Departamento de Ciencia y Producción Agropecuaria, Escuela Agrícola Panamericana El Zamorano, Tegucigalpa, Honduras) and the anonymous reviewers for their help. Financial support was provided by Conselho Nacional de Desenvolvimento Científico e Tecnológico (CNPq, grant 444320/2014-8), Brazil. This paper is part of the SIGMA project No21565 MN/UFRJ and contribution number 36 from the HYMN.

\section{References}

Alfken J.D. 1904. Notas Himenopterolójicas. I. Sinonimia de abejas (Apidae) chilenas. Revista chilena de Historia natural 8: 141.

Anonymous 1975. The President's remarks. Proceedings of the Royal Entomological Society of London, Series C Journal of Meetings 39: 55-58.

Ayala R. 2002. Two new subgenera of bees in the genus Centris (Hymenoptera: Apidae). Scientific Papers (Natural History Museum, the University of Kansas) 25: 1-8. https://doi.org/10.5962/bhl.title.8484

Barragán A.R., Dangles O., Cárdenas R.E. \& Onore G. 2009. The history of entomology in Ecuador. Annales de la Société entomologique de France (n.s.) 45: 410-423.

https://doi.org/10.1080/00379271.2009.10697626

Burger W. 1991. Louis Otho Williams (1908-1991). Taxon 40: 355-356.

Cameron P. 1903. Descriptions of new species of Hymenoptera taken by Mr. Edward Whymper on the "higher Andes of the Equator". Transactions of the American Entomological Society 29: 225-328.

Caudell A.N. 1907. On some earwigs (Forficulidae) collected in Guatemala by messrs. Schwarz and Barber. Proceedings of the United States National Museum 33 (1563): 169-176.

Cockerell T.D.A. 1897a. XXXIX. - Contributions from the New Mexico Biological Station. V. - Some new Hymenoptera from the Mesilla Valley, New Mexico. The Annals and Magazine of Natural History 19 (112): 394-403. https://doi.org/10.1080/00222939708680555

Cockerell T.D.A. 1897b. New and little-known North American bees. Proceedings of the Academy of Sciences of Philadelphia 49: 334-355.

Cockerell T.D.A. 1899. Notes on the nomenclature of some Hymenoptera. The Entomologist 32: 14.

Cockerell T.D.A. 1900. Notes on New Mexico bees. The Canadian Entomologist 32: 361-364.

https://doi.org/10.4039/Ent30146-6

Cockerell T.D.A. 1904a. Bees of southern California VI. Bulletin of the Southern California Academy of Sciences 3 (9): 159-162.

Cockerell T.D.A. 1904b. New records of bees. The Entomologist 37: 231-236.

Cockerell T.D.A. 1910. Some Neotropical bees. Psyche: A Journal of Entomology 17: 142-144. https://doi.org/10.1155/1910/35751

Cockerell T.D.A. 1912a. The Stanford expedition to Brazil, 1911: new bees from Brazil. Psyche: A Journal of Entomology 19: 41-61. https://doi.org/10.1155/1912/25740

Cockerell T.D.A. 1912b. LXII. - Description and records of bees. - XLIV. Annals and Magazine of Natural History 9 (53): 554-568. https://doi.org/10.1080/00222931208693171

Cockerell T.D.A. 1912c. XIV. - Description and records of bees. - XLI. Annals and Magazine of Natural History 9 (49): 139-149. https://doi.org/10.1080/00222931208693114 
Cockerell T.D.A. 1913. XV. - Description and records of bees. - LIII. Annals and Magazine of Natural History 12 (67): 103-110. https://doi.org/10.1080/00222931308693377

Cockerell T.D.A. 1914. Bees from Ecuador and Peru. Journal of the New York Entomological Society 22 (4): 306-328.

Cockerell T.D.A. 1917. XLVI. - Descriptions and records of bees. - LXXV. Annals and Magazine of Natural History 19 (114): 473-481. https://doi.org/10.1080/00222931709486965

Cockerell T.D.A. 1919. Bees in the collection of the United States National Museum. 3. Proceedings of the United States National Museum 55: 167-221. https://doi.org/10.5479/si.00963801.55-2264.167

Cockerell T.D.A. 1922. Bees in the collection of the United States National Museum. 4. Proceedings of the United States National Museum 60: 1-20. https://doi.org/10.5479/si.00963801.60-2413.1

Cockerell T.D.A. 1923. Expedition of the California Academy of Sciences to the Gulf of California in 1921. The Bees (I). Proceedings of the California Academy of Sciences 12 (7): 73-103.

Cockerell T.D.A. 1924. Anthophorid bees in the collection of the California Academy of Sciences. The Pan-Pacific Entomologist 1: 49-56.

Cockerell, T.D.A. 1926a. XXVIII. - Descriptions and records of bees. - CVIII. Annals and Magazine of Natural History 17 (98): 214-226. https://doi.org/10.1080/00222932608633395

Cockerell T.D.A. 1926b. The black bees of Peru. The Entomologist 59: 28-29.

Cockerell T.D.A. 1935a. Recollections of a Naturalist. Bios 6 (4): 372-385.

Cockerell T.D.A. 1935b. New bees from Trinidad. Stylops 4 (1): 10-13.

https://doi.org/10.1111/j.1365-3113.1935.tb01291.x

Cockerell T.D.A. 1936. LXIV. - Descriptions and records of bees. - CLVIII. Annals and Magazine of Natural History 18 (108): 631-638. https://doi.org/10.1080/00222933608655236

Cockerell T.D.A. 1937a. South American bees. American Museum Novitates 928: 1-2.

Cockerell T.D.A. 1937b. XXXI. - Descriptions and records of bees. - CLXIV. Annals and Magazine of Natural History 20 (117): 280-286. https://doi.org/10.1080/00222933708655343

Cockerell T.D.A. 1938. Bees from St. Vincent, British West Indies. The Entomologist 71: 280-283.

Cockerell T.D.A. 1939. Bees of the genus Centris from Barbados, B.W.I. The Entomologist 72: 142.

Cockerell T.D.A. 1949. Bees from Central America, principally Honduras. Proceedings of the United States National Museum 98: 429-490. https://doi.org/10.5479/si.00963801.98-3233.429

Cresson E.T. 1879. Descriptions of new North American Hymenoptera in the collection of the American Entomological Society (family Apidae). Transactions of the American Entomological Society 7: 201-232.

Davenport C.B. 1937. Biographical memoir of George Davidson, 1825-1911. National Academy of Sciences of the United States of America Biogeographical Memoirs 18: 188-217.

Ducke A. 1908. Contribution à la connaissance de la faune Hyménoptérologique du Nord-Est du Brésil II. Hyménoptères récoletés dans l'État de Ceara en 1908. Revue d'Entomologie 27 (6): 57-87.

Engel M.S. \& Davis S.R. 2012. 75 years ago in bee systematics: Cockerell on "the evolution of the bees". Journal of the Kansas Entomological Society 85 (2): 170-172. https://doi.org/10.2317/JKES120423.1

Erichson W.F. 1848. Insecten. In: Schomburgk R. (ed.) Reisen in Britisch-Guiana in den Jahren 1840-1844. Im Auftrag Sr. Mägestat des Königs von Preussen. Vol. III: 553-617. Weber, Leipzig.

Evenhuis N.L. 2013. Charles Henry Tyler Townsend (1863-1944): man of wanderlust and mystery. Fly Times 50: 15-24. 
Fabricius J.C. 1775. Systema Entomologiae sistens insectorum Classes, Ordines, Genera, Species, adjectis Synonymis, Locis, Descriptionibus, Observationibus. Korte, Flensburg and Leipzig [Flensburgi et Lipsiae].

Fabricius J.C. 1804 Systema Piezatorum secundum Ordines, Genera, Species, adjectis Synonymis, Locis, Observationibus, Descriptionibus. Reichard, Brunswick [Brunsvigae].

Fox W.J. 1899. Synopsis of the United States species of the hymenopterous genus Centris Fabr. with description of a new species from Trinidad. Proceedings of the Academy of Natural Sciences of Philadelphia 51: 63-70.

Friese H. 1899 (1900). Neue Arten der Bienengattungen Epicharis Klug und Centris Fabr. Természetrajzi Füzetek 23: 39-48.

Friese H. 1901 (1900). Monographie der Bienengattung Centris (s. lat). Annalen des kaiserlich-königlich naturhistorischen Hofmuseums (Wien) 15: 237-350.

Friese H. 1904. Nachtrag zur Monographie der Bienengattung Centris. Annales Musei nationalis hungarici 2: 90-92.

Gardner S.A. 1999. Theodore Dru Alison Cockerell. American National Biography 5: 123-124.

Günther A. 1912. The History of the Collections Contained in the Natural History Departments of the British Museum: General History of the Department of Zoology from 1856 to 1895. Vol. 2. Publication of the Trustees of the British Museum, London.

Herbst P. 1918. Nuevas avispas antófilas de Chile (Apidae, Hymenoptera). Revista chilena de Historia natural 22: 149-152.

Holland W.J. 1919. Obituary notes. Herbert Huntington Smith. Annals of the Carnegie Museum 12: $353-358$.

Horn W. \& Kahle P.H.I. 1935. Über entomologische Sammlungen. I. Kapitel: Sammlungen welche ihren Eigentümer gewechselt haben (nebst Angaben über Ausbeuten von Expeditionen, Privat-Sammlern und Händlern). Entomologische Beihefte Berlin-Dahlem 2: 1-160.

Howard L.O. 1928. Dr. E.A. Schwarz. Proceedings of the Entomological Society of Washington 30 (9): 154-183.

International Commission on Zoological Nomenclature. 1999. International Code of Zoological Nomenclature, Fourth Ed. International Trust for Zoological Nomenclature, London.

Klug J. 1807. Kritische Revision der Bienengattungen in Fabricius neuem Piezatensysteme mit Berücksichtigung der Kirbyschen Bienenfamilien und Illiger's Bemerkunde zu Kirbys Monographie. Magazin für Insektenkunde 6: 200-228.

Lepeletier A.L.M. 1841. Histoire naturelle des Insectes. Hyménoptères. Vol. II. Librairie encyclopédique de Roret, Paris.

Lhoste J. 1987. Les Entomologistes français. 1750-1950. Institut national de la Recherche agronomique, Paris.

MacFarland F.M. 1940. Edward Payson Van Duzee. Science 92 (2379): 99.

https://doi.org/10.1126/science.92.2379.99

Michener C.D. 1948. T.D.A. Cockerell. Journal of the New York Entomological Society 56 (3): 171-174.

Michener C.D. 1954. Bees of Panama. Bulletin of the American Museum of Natural History 104: 1-176.

Michener C.D. 2007. The Bees of the World, Second Ed. Johns Hopkins University Press, Baltimore.

Mocsáry A. 1899. Species novae generis Centris Fabr. in collectione Musæi Nationalis Hungarici. Természetrajzi Füzetek 22: 251-255. 
Moret P. 2005. Los coleópteros Carabidae del páramo en los Andes del Ecuador. Sistemática, ecología y biogeografia. Museo de Zoología, Centro de Biodiversidad y Ambiente, Escuela de Biología. Pontificia Universidad Católica del Ecuador, Quito.

Moure J.S. 1945. Apoidea da coleção do Conde Amadeu A. Barbiellini. II. (Hym. Apoidea). Revista de Entomologia 16 (3): 394-414.

Moure J.S. 1950. Alguns agrupamentos novos de abelhas neotropicais. Dusenia 1 (6): 385-396.

Moure J.S. 1960. Notes on the types of the Neotropical bees described by Fabricius (Hymenoptera: Apoidea). Studia Entomologica 3(1-4): 97-160.

Moure J.S. 1969. Notas sôbre algumas espécies de Centris da Guiana (Hym., Apoidea). Anais da Academia brasileira de Ciências 41 (1): 114-123.

Moure, J.S. 2002. O subgênero Centris (Aphemisia) Ayala: notas complementares e descrição de uma nova espécie (Hymenoptera, Apoidea). Revista brasileira de Entomologia 46 (3): 257-261. https://doi.org/10.1590/s0085-56262002000300006

Moure J.S., Melo G.A.R. \& Vivallo F. 2007. Centridini Cockerell \& Cockerell. In: Moure J.S., Urban D. \& Melo G.A.R. (orgs) Catalogue of Bees (Hymenoptera, Apoidea) in the Neotropical Region: 83-142. Sociedade Brasileira de Entomologia, Curitibrazil.

Oliveira A.L. 2014. O litoral do Nordeste do Brasil como objeto científico darwinista: as prospecções de John Casper Branner, 1899-1911. História, Ciências, Saúde-Manguinhos 21 (3): 931-949. https://doi.org/10.1590/S0104-59702014000300008

Pérez J. 1905. Hyménoptères nouveaux du Mexique. Bulletin, Museum d'historie Naturalle, Paris 11: $39-41$.

Pitty A. 2008. Amado Pelén Cantoral, una vida dedicada al servicio de la Escuela Agrícola Panamericana. Revista Ceiba 49: 1-6.

Pourshariati K. 2017. John W. Ogilvie Papers. University of Pennsylvania, Penn Museum Archives.

Rasmussen C. \& Vivallo F. 2014. Lectotype designations and new synonymies in the Neotropical bee genus Centris Fabricius, 1804 (Hymenoptera: Apidae). Zootaxa 3856 (4): 585-594.

https://doi.org/10.11646/zootaxa.3856.4.7

Rathbun R. 1911. Report on the Progress and Condition of the U. S. National Museum for the Year ending June 30, 1910. Government Printing Office, Washington.

Rohwer S.A. 1948. Theodore Dru Alison Cockerell 1866-1948. Proceedings of the Entomological Society of Washington 50 (4): 103-108.

Roig-Alsina A. 2000. Claves para las especies argentinas de Centris (Hymenoptera, Apidae), con descripción de nuevas especies y notas sobre distribución. Revista del Museo argentino de Ciencias naturales (n.s.) 2 (2): 171-193.

Salt G. 1955. Prof. C.T. Brues. Nature 176: 628. https://doi.org/10.1038/176628a0

Schwarz H.F 1948. Theodore Dru Alison Cockerell 1866-1948. Science 108 (2803): 295-296. https://doi.org/10.1126/science.108.2803.295

Smith F. 1854. Catalogue of Hymenopterous Insects in the Collection of the British Museum, Part 2 Apidae: 199-465. British Museum, London.

Smith F. 1874. XLIX: - A revision of the genera Epicharis, Centris, Eulema, and Euglossa belonging to the family Apidae, section Scopulipedes. Annals and Magazine of Natural History (ser. 4) 13 (77): 357-373. https://doi.org/10.1080/00222937408680879

Smithsonian Institution Archives. 2019. Record Unit 7297, Melbourne Armstrong Carriker Papers. Available from https://siarchives.si.edu/collections/siris_arc_217454 [accessed 15 Apr. 2019]. 
Snelling R.R. 1956. Bees of the genus Centris in California. The Pan-Pacific Entomologist 32: 1-8.

Snelling R.R. 1966. The taxonomy and nomenclature of some North American bees of the genus Centris with description of new species (Hymenoptera: Anthophoridae). Contributions in Science, Los Angeles County Museum of Natural History 112: 1-33.

Snelling R.R. 1974. Notes on the distribution and taxonomy of some North American Centris (Hymenoptera: Anthophoridae). Contributions in Science, Los Angeles County Museum of Natural History 259: 1-41.

Snelling R.R. 1984. Studies on the taxonomy and distribution of American Centridine bees (Hymenoptera: Anthophoridae). Contributions in Science, Los Angeles County Museum of Natural History 347: 1-69.

Spinola M. 1851. Hyménopteros. In: Gay C. (ed.) Historia Física y Política de Chile. Zoología. Vol. 6: 153-569. Casa del autor, Paris.

Usinger R.L. 1959. Gordon Floyd Ferris1893-1958. The Pan-Pacific Entomologist 35 (1-4): 1-12.

Velarde C.N. 2006. Edmundo Escomel. Acta médica peruana 23: 193-195.

Vivallo F. 2013. Revision of the bee subgenus Centris (Wagenknechtia) Moure, 1950 (Hymenoptera: Apidae: Centridini). Zootaxa 3683 (5): 501-537. https://doi.org/10.11646/zootaxa.3683.5.1

Vivallo F. 2019. Lectotype designations, taxonomic notes and new synonymies in some species of the bee genus Centris Fabricius, 1804 described by Amédée Lepeletier de Saint-Fargeau (Hymenoptera: Apidae). Zootaxa 4624 (1): 23-40. https://doi.org/10.11646/zootaxa.4624.1.2

Vivallo F. 2020. Lectotype designations, taxonomic notes and new synonymies in some species of the bee genus Centris Fabricius, 1804 described by Frederick Smith (Hymenoptera: Apidae). Zootaxa 4729 (2): 151-176. https://doi.org/10.11646/zootaxa.4729.2.1

Weber W.A. 2004. The Valley of the Second Sons: Letters of Theodore Dru Alison Cockerell, a Young English Naturalist, Writing to his Sweetheart and her Brother about his Life in West Cliff, Wet Mountain Valley, Colorado 1887-1890. Pilgrims Process Inc, Longmont.

Zanella F.C.V. 2002. Sistemática, filogenia e distribuição geográfica das espécies sul-americanas de Centris (Paracentris) Cameron, 1903 e de Centris (Penthemisia) Moure, 1950, incluindo uma análise filogenética do grupo Centris, sensu Ayala, 1998 (Hymenoptera: Apoidea: Centridini). Revista brasileira de Entomologia 46 (4): 435-488. https://doi.org/10.1590/s0085-56262002000400001

Zuparko R.L. 2007. The published names of TDA Cockerell.

Available from https://essig.berkeley.edu/publications/cockerel1/ [accessed 18. Mar. 2020].

Manuscript received: 14 May 2019

Manuscript accepted: 19 December 2019

Published on: 19 March 2020

Topic editor: Gavin Broad

Desk editor: Radka Rosenbaumová

Printed versions of all papers are also deposited in the libraries of the institutes that are members of the EJT consortium: Muséum national d'histoire naturelle, Paris, France; Meise Botanic Garden, Belgium; Royal Museum for Central Africa, Tervuren, Belgium; Royal Belgian Institute of Natural Sciences, Brussels, Belgium; Natural History Museum of Denmark, Copenhagen, Denmark; Naturalis Biodiversity Center, Leiden, the Netherlands; Museo Nacional de Ciencias Naturales-CSIC, Madrid, Spain; Real Jardín Botánico de Madrid CSIC, Spain; Zoological Research Museum Alexander Koenig, Bonn, Germany; National Museum, Prague, Czech Republic. 